\title{
Ampliando Horizontes Para o Turismo no Rio da Prata de Campo Grande a Partir da Perspectiva do Uso Público no Parque Estadual da Pedra Branca (RJ)
}

\author{
Maria Amália Silva Alves de Oliveira ${ }^{a}$ \\ Ingrid Almeida de Barros Pena ${ }^{b}$ \\ Roberta Peixotoc
}

\begin{abstract}
Resumo
O presente trabalho investigou o processo de turismização da vertente do Rio da Prata do Parque Estadual da Pedra Branca sob o prisma do Uso Público, pois o saber produzido a partir de tais processos apresenta relevância para o planejamento e gestão de atividades de visitação cuja experiência tenha como fim a conservação. Realizou-se revisão da literatura, aplicação de questionários semiabertos, entrevistas e observação participante. Foram consultados moradores, visitantes, técnicos do órgão ambiental e condutores locais. A partir das informações coletadas, discutimos representações de turismo, oportunidades e desafios relacionados ao Uso Público, e os resultados do "Curso de Condutor de Visitantes do PEPB". Apresentamos recomendações para futuras qualificações ofertadas pelo órgão ambiental e concluímos que, além deste, outros órgãos/setores deveriam estar envolvidos no processo de indução de turismo no local.
\end{abstract}

Palavras-chave: Comunidade receptora; Ecoturismo; Unidades de conservação; Gerenciamento de visitação.

\section{Abstract \\ Expanding Horizons for Tourism at Rio da Prata/Campo Grande From the Perspective of Public Use in the Pedra Branca State Park (RJ)}

This work investigates the tourism process of Rio da Prata, an area inside Pedra Branca State Park, through the viewpoint of Public Use, considering that the knowledge produced from public use processes is relevant to the planning and management of visitation activities which aim at conservation. Literature review, semi-open questionnaires, interviews and participant observation were carried out. Residents, visitors, technicians from the environmental agency and local guides were consulted. Based on the information collected, we discuss the representations of tourism, the opportunities and challenges related to Public Use, and the results of the "PEPB Local Guide Training Course". We present recommendations for future qualifications offered

a. Doutor em Ciências Humanas com concentração em Antropologia pela Universidade Federal do Rio de Janeiro (UFRJ). Docente de Graduação em Turismo; Programa de Pós-Graduação em Memória Social; e Programa de Pós- Graduação em Ecoturismo e Conservação na Universidade Federal do Estado do Rio de Janeiro (UNIRIO). Rio de Janeiro, Rio de Janeiro, Brasil. E-mail: maria.oliveira@unirio.br.

b. Doutoranda em Geografia e Meio Ambiente pela Pontifícia Universidade Católica do Rio de Janeiro (PUC/Rio). Rio de Janeiro, Rio de Janeiro, Brasil. E-mail: ingrid.pena@gmail.com.

c. Mestre em Memória Social pela Universidade Federal do Estado do Rio de Janeiro (UNIRIO). Rio de Janeiro, Rio de Janeiro, Brasil. E-mail: beta-peixoto@hotmail.com. 
by the environmental agency and conclude that in addition to the environmental agency, other sectors should be involved in local tourism promotion.

Keywords: Local community; Ecotourism; Conservation units; Visitation management.

\section{Resumen}

Expandiendo Horizontes Para el Turismo en el Rio da Prata en Campo Grande Desde la Perspectiva del Uso Público en el Parque Estatal Pedra Branca (RJ)

El presente trabajo investigó el proceso de "turismización" em Rio da Prata, vertiente del Parque Estatal Pedra Branca, bajo el prisma de Uso Público, considerando que el conocimiento producido a partir de esos procesos es relevante para la planificación y gestión de actividades de visitación cuya experiencia está dirigida a la conservación. Se realizaron revisión de literatura, cuestionarios semiabiertos, entrevistas y observación participante. Se consultó a residentes, visitantes, técnicos de la agencia ambiental y conductores locales. Con base en la información recopilada, discutimos las representaciones del turismo, las oportunidades y los desafíos relacionados con el uso público, y los resultados del "Curso de Conductor de Visitantes PEPB". Presentamos recomendaciones para futuras calificaciones ofrecidas por la agencia ambiental y concluimos que además de esto, otros organismos / sectores deberían estar involucrados en el proceso de inducir el turismo en el área.

Palabras clave: Comunidad local; Ecoturismo; Unidades de conservación; Gestión de visitas.

\section{INTRODUÇÃO}

0 turismo de natureza está fortemente associado às áreas rurais (PérezCalderón et. al, 2020). Assim como o cenário natural, o cenário rural apresenta significados e valores socioculturais e históricos que proporcionam ao homem urbano simbologias valorativas no que tange ao processo de preservação e manutenção das raízes culturais (Santos, Emiliano \& Pagamisse, 2012). Em ambos cenários, permeia a preocupação pela utilização sustentável do patrimônio natural e cultural e o desenvolvimento de atividades que representem uma "conciliação" do homem com a natureza. A se pensar consoante a Perez-Calderón et. al. (2020), as áreas protegidas próximas a áreas rurais podem ser consideradas um meio adequado de combinar atividades tradicionais com novos nichos de negócios associados ao turismo rural e natural, com o objetivo de promover o desenvolvimento nas áreas de influência.

No Brasil, as Unidades de Conservação (UC) são consideradas territórios de excelência para o desenvolvimento do ecoturismo (Fontoura, 2014). A forma de utilização e aproveitamento das UC por meio da visitação, qualquer que seja a motivação, é conceituada pelo termo "Uso Público" (UP). Esse é o modo pelo qual se estabelece, de acordo com Rosa (2017), a integração entre espaço natural e moradores, visitantes, educadores e pesquisadores, favorecendo a incorporação deste pela sociedade e viabilizando agregar valor social à UC, de acordo com os princípios de conservação da biodiversidade e desenvolvimento socioeconômico.

Com 12.393,84 hectares, o Parque Estadual da Pedra Branca (PEPB) é considerado uma das maiores florestas urbanas do mundo (INEA, 2013) e abriga importantes atrativos naturais e culturais, como o Pico da Pedra Branca, ponto 
mais alto do Rio de Janeiro, e a Pedra do Telégrafo, que nos últimos anos se destacou como um dos principais atrativos da cidade, recebendo 45.670 visitantes em 2018 ${ }^{1}$. O parque foi criado em 1974, para proteger importantes fragmentos de Mata Atlântica, e está situado na zona oeste do município do Rio de Janeiro, onde o processo socioeconômico, político e cultural de integração foi construído em torno da ideia de vocação agrícola.

O PEPB é uma das UC estaduais que mais recebe visitantes, sendo superada apenas pelo Parque Estadual da Costa do Sol, pelo Parque Estadual da Ilha Grande e pelo Parque Estadual da Serra da Tiririca². Entretanto, como o monitoramento da visitação ainda não é realizado de forma padronizada pelo Instituto Estadual do Meio Ambiente (INEA), autarquia ambiental fluminense responsável pela gestão das áreas protegidas, estima-se que o parque receba um número de visitantes ainda maior do que o estipulado. ${ }^{3}$

Diante da necessidade de incentivo e ordenamento das atividades de UP no PEPB, foi realizado pelo INEA, em 2016, o Curso de Condutor de Visitantes do Parque Estadual da Pedra Branca, voltado para a capacitação de condutores locais. A demanda pelo curso começou a ser identificada durante reuniões do Conselho Consultivo do PEPB, realizadas em 2015. Nessas ocasiões, registram Pena e Moss (2017), alguns moradores da vertente oeste do parque (especialmente de Rio da Prata de Campo Grande, Guaratiba, Pedra de Guaratiba e Barra de Guaratiba) entraram em contato com a equipe da gestão do PEPB, solicitando maior atenção a estas regiões, no contexto de promoção e ordenamento de atividades relacionadas a ecoturismo.

A região do Rio da Prata, recorte espacial de análise deste trabalho, apesar de compor oficialmente a área urbana da cidade, apresenta remanescentes de uma cultura rural. Nesta vertente, ainda existem áreas de roçado e residências familiares situadas no interior da UC. A sobreposição entre UC e áreas historicamente utilizadas por comunidades agrícolas e/ou tradicionais gera conflitos que fazem parte da realidade de diversas UC no Brasil (MMA, 2015). Fernandez (2016) analisa o histórico de ocupação do Maciço da Pedra Branca e da trajetória dos produtores agrícolas, e revela o desejo desse grupo social de subverter as representações estigmatizantes de invasores e depredadores ambientais, fazendo um pacto ambiental que parte do reconhecimento de seu papel na conservação das suas fronteiras.

Assim, decorreu um processo de reenquadramento social dessas comunidades ao longo de ciclos de produção para que pudessem permanecer habitando e produzindo nos mesmos locais (Leal, 2010; Prado, 2012). Compreendemos que o processo de "turismização" (Mendonça, 2010) que acontece na região, além de contribuir com o pacto supracitado, resulta em impactos relacionados ao turismo como negócio, e como fenômeno que altera relações sociais. Tais processos devem ser levados em conta no planejamento do UP.

De acordo com Mendonça (2010), o conceito de "turistificação" toma o espaço como elemento de intervenção e apropriação pelo turismo, enquanto o conceito

1. Registrado por meio de um eco-contador, ferramenta utilizada para contagem de visitantes a partir de suas pisadas no aparelho.

2. Informação cedida, via e-mail, pela equipe técnica da Gerência de Visitação, Negócios e Sustentabilidade (GEVINS) do INEA

3. Ibidem. 
de "turismização" designa fenômenos - ou percepções destes - a partir da perspectiva de um processo. Assim, turismização é um processo histórico de construção de um fenômeno associado a um processo de interiorização das diferentes facetas do turismo pelos grupos e pelas pessoas, que influencia nas relações e no modo de vida de determinado lugar (Mendonça, 2010). Neste trabalho, turismização remete também à transformação do espaço, mas em um processo que considera o contexto global e universalizante, que é responsável não apenas pela alteração no estatuto e na utilização dos lugares, mas também pela influência nas relações, modos de vida e identidades.

O negócio do turismo tem alta relevância no desenvolvimento econômico e social. Em 2019, registrou crescimento de 3,5\%, superando o da economia global $(2,5 \%)$ pelo nono ano consecutivo (WTTC, 2020a). No mesmo ano, o Brasil foi a $12^{\circ}$ economia no mundo em impacto do turismo no PIB (WTTC, 2020b). Na última década, a atividade turística associada às áreas naturais se destacou como propulsora de desenvolvimento econômico (Perez-Calderón et. al, 2020). Em 2018, entre os turistas que visitaram o Brasil a lazer, 16\% procuraram pelo ecoturismo (Embratur, 2019). Além disso, segundo o MTur (2019), o país é considerado o primeiro em atrativos naturais no ranking de competitividade do Fórum Econômico Mundial.

É crescente uma demanda turística cada vez mais exigente, ambiental e socialmente consciente. 0 turismo de massa se demonstrou insustentável, dando espaço a um modelo de gestão turística cujos protagonistas são os agentes locais do território (Zaoual, 2008). Essa tendência, aliada ao aumento do ecoturismo em parques (MTur, 2020), tem alterado o fluxo de pessoas na região aqui estudada e produzido bens simbólicos, que atraem visitantes para locais próximos e dentro do parque.

A questão ambiental é incorporada na reorientação do olhar para o meio rural e observa-se a produção de elementos revalorizados, tendo os recursos naturais e as práticas "tradicionais" a eles associados. Neste processo, ganha relevo o debate entre turismo e UP - vulgarmente associado à prática turística. Buscamos, então, demonstrar que ações existentes no âmbito da atividade turística ajudam a pensar o UP em UC. Desta forma, UP é aqui entendido como um conjunto de ações voltadas para o planejamento e ordenamento de UC, sendo essas ações ancoradas em distintos tipos de visitação.

Deste modo, o artigo se propõe a apresentar a análise da experiência do Curso de Condutor de Visitantes do PEPB, promovido pelo INEA, que teve como desdobramento a mudança na percepção dos atores envolvidos na turismização da UC e seu entorno. Diante do exposto, este trabalho tem como objetivo investigar, sob o prisma do UP, o processo de "turismização" da vertente do Rio da Prata do PEPB, tomando como referência o supracitado curso, na expectativa de suprir a escassez de estudos de tal natureza e que se encaixem na perspectiva do que as autoras e a gestão do Parque consideram e denominam como ecoturismo. É, portanto, relevante destacar que este segmento da atividade turística se baseia na premissa de que, para o pleno alcance da conservação dos recursos naturais, há de se considerar a comunidade receptora, neste caso, os moradores. 


\section{PROCEDIMENTOS METODOLÓgICOS E ABORDAGEM TEÓRICA DE ANÁLISE}

Metodologicamente, este artigo foi construído a partir dos resultados de distintas técnicas de pesquisa aplicadas em diferentes etapas do processo que tem orientado a investigação em curso. De acordo com Oliveira (2015), é possível enquadrar o conjunto de procedimentos metodológicos na denominada abordagem multimétodo, que combina métodos quantitativos e qualitativos. Segundo a autora, tal abordagem é também conhecida como triangulação metodológica, sendo uma das formas mais completas de pesquisa empírica.

A opção pela combinação de métodos quantitativos e qualitativos teve por base a decisão de produzir uma reflexão em que aspectos teóricos e conceituais assentem-se em um modelo de compreensão preconizado por Tribe (1997). Tal autor considera o turismo enquanto campo de estudos ${ }^{4}$, composto por dois grandes campos: o campo dos negócios turísticos e outro, que se dedica aos âmbitos das implicações relativas a percepções, natureza, cultura, entre outros.

Concordando com Tribe (1997), consideramos que tais campos não são mutuamente excludentes, mas complementares. Nesta perspectiva teórico-conceitual, insere-se a utilização do conceito de turismização (Mendonça, 2010), já explorado e definido na sessão anterior, e o conceito de representações sociais. Para Horochovski (2004), a teoria das representações coletivas de Emile Durkheim inaugura, no âmbito da Sociologia, uma forma de analisar a realidade coletiva, pautada na apreensão dos conhecimentos, crenças e sentimentos do grupo social. Posteriormente, foi trabalhada em termos de representações sociais por Serge Moscovici, no âmbito da Psicologia Social.

Moscovici (1978), ao alterar o termo "coletivo" por "social", amplia seu sentido, incluindo em tal perspectiva a possibilidade de produção de conhecimentos. Em ambas, o que está em jogo é uma categoria de análise social. Interpretada enquanto instrumento de pesquisa, tal categoria permite entender as concepções dos grupos em estudo, oferecendo uma base de compreensão de mudanças e permanências ou, ainda, continuidades e rupturas, promovidas no contexto da interação social.

Assim, os conceitos de turismização e de representações sociais, ancorados na teoria de Tribe (1997) e orientados pela abordagem multimétodo, favoreceram a agregação de contextos. E cujos resultados contribuem com pesquisas sobre visitação turística em UC, com a produção de dados para gestão e ordenamento do Uso Público e para estudos sobre grupos culturais tradicionais em interface com o turismo.

Foi feita uma revisão da literatura sobre o PEPB, com foco na vertente do Rio da Prata, em artigos científicos, teses e relatórios técnicos. As plataformas de busca utilizadas foram Scielo e Google Scholar. Também foram selecionados trabalhos a partir da consulta com pesquisadores que participam do Conselho Consultivo do PEPB. À revisão, foram acrescentadas notas tomadas em observações em campo, em participação em reuniões do Conselho Consultivo e em eventos no local.

4. O autor retoma o conceito de disciplina e de campo de estudos, esclarecendo que disciplina é uma forma de estudar e produzir conhecimento, dotada de conceitos, teorias e métodos de pesquisa próprios; enquanto o campo de estudos é um objeto a ser estudado e cuja natureza se constitui por várias disciplinas. 
Para a análise do perfil e percepção dos visitantes em relação ao PEPB e ao turismo no Rio da Prata, foram aplicados 63 questionários semiestruturados, entre dezembro de 2018 e março de 2019, regularmente aos domingos, entre 9:00 e 14:00 horas. 0 local escolhido para a aplicação dos questionários foi o Sitio Farol da Prata. Nele reúnem-se interessados nas trilhas do parque e nos atrativos locais, e onde, aos domingos, é oferecido o "Café na Roça”, descrito na próxima seção deste trabalho.

Para a análise dos desdobramentos da implementação do Curso de Condutor, aplicamos um questionário com perguntas fechadas e semiabertas para os então formados condutores locais, verificando as suas expectativas e percepções antes e depois do curso. 0 questionário foi enviado por meio de um grupo virtual, estando disponível para acesso em março e abril de 2018, aproximadamente dois anos após a implementação do curso. Apenas 13 dos 31 condutores responderam.

Foram entrevistados três moradores envolvidos no processo de turismização do Rio da Prata, sendo sujeitos sociais influentes na localidade; e dois técnicos do INEA envolvidos implementação do Projeto de Uso Público. Para preservar a identidade dos entrevistados, optamos por omitir seus nomes, mas representam os seguintes envolvimentos na comunidade: 1) educação formal e não formal (E); 2) prestação de serviços turísticos (P);3) associação de agricultores orgânicos (A); 4) órgão público responsável pela gestão do UP do PEPB (INEA).

As entrevistas foram constituídas de perguntas abertas, sendo realizadas entre agosto de 2018 e setembro de 2019 . 0 objetivo foi captar diferentes nuances sobre as percepções e concepções dos entrevistados, considerando os eixos de pesquisa dos quais este trabalho faz parte, incluindo o que é turismo e o que é o próprio local para eles. As respostas foram transcritas e a codificação foi feita manualmente, resultando em três categorias: I) representações do Turismo, II) principais oportunidades e desafios relacionados ao turismo, e III) percepções sobre o Curso de Condutor de Visitantes.

Destacamos que não reconhecemos como limitação do estudo a quantidade de entrevistados. Pois, de acordo com a perspectiva antropológica, um grupo social pode ser compreendido a partir das percepções, concepções e visões de mundo de um de seus representantes. Isto, uma vez que este carrega em si, em maior ou menor grau, os valores inerentes a todo o grupo.

Contextualizada a partir de um enquadramento teórico-conceitual inserido na interface entre turismo e distintas áreas do conhecimento, a adoção da abordagem multimétodo resultou em diferentes níveis de conhecimento acerca dos fenômenos sociais no âmbito da prática turística, atendendo de forma precisa às questões centrais que buscamos responder neste artigo.

\section{RESULTADOS}

As atividades de UP nos Parques Estaduais do Rio de Janeiro receberam atenção nos últimos anos, em especial a partir do decreto no 42.483, de 27 de maio de 2010, que estabelece diretrizes para o UP nos parques administrados pelo INEA. Desde então, foram desenvolvidos projetos de fortalecimento e consolidação do UP em 12 parques, incluindo o PEPB. Os projetos envolveram investimentos de infraestrutura, ações de incremento à visitação, implementação e manejo de uma rede de trilhas, encontros científicos, eventos, ações de interpretação ambiental, entre outros. 
Na vertente do Rio da Prata, duas ações merecem destaque: a implementação do Curso de Condutores e o incentivo à implementação e divulgação da Trilha Transcarioca, que passa pelo PEPB e atrai milhares de caminhantes. A trilha não conta com a plena adesão da comunidade, devido, em grande parte, a um histórico conflituoso entre a comunidade e a gestão do Parque. A despeito das duas ações estarem interligadas, nos deteremos na análise do curso, pois consideramos que reside nesta ação um esforço de inclusão da comunidade, uma vez que tal capacitação esteve direcionada à inserção da comunidade local receptora, aspecto que evidencia uma preocupação em instituir as bases do ecoturismo, conforme as orientações básicas do Ministério do Turismo (MTur, 2010).

\section{a) Rio da Prata de Campo Grande: contextualização e iniciativas de Uso Público}

A sobreposição entre UC e áreas utilizadas por comunidades tradicionais, ao mesmo tempo que amplia desafios, pode representar oportunidades para residentes, turistas, gestores públicos e privados (Penna-Firme \& Brondízio, 2017). Os agricultores do Rio da Prata têm suas propriedades - sítios e roças - em áreas com histórico de uso agrícola, sofrem forte pressão da urbanização e restrições devido a estarem próximos ou dentro dos limites de uma área de preservação (Prado, 2012).

A criação do Parque submeteu produtores agrícolas a uma legislação específica, que define as formas de acesso, ocupação e uso da terra e dos recursos naturais, impulsionando a "conversão" dos pequenos agricultores da região do Rio da Prata em agricultores orgânicos (Leal, 2010). Com isso, os agricultores se tornaram aptos a integrar um mercado especializado de comercialização de produtos agrícolas. Atualmente, a principal atividade orientada ao mercado é o manejo agroflorestal tradicional da banana e do caqui, sem uso de agroquímicos, ao mesmo tempo em que as feiras agroecológicas têm estimulado a produção de uma série de outros bens alimentares consorciados. Além disso, a "conversão" (Leal, 2010) - ou seja, o processo de mudança da forma de produção tradicional para orgânica - também fez com que se aliassem a redes e espaços de participação.

Com essa readequação social, e estando em pauta debates acerca da presença de comunidades dentro e no entorno de áreas protegidas, o modo de vida de tais agricultores passou, nos últimos anos, a ser designado como "tradicional", ou seja,

próprio de grupos culturalmente diferenciados e que se reconhecem como tais, que possuem formas próprias de organização social, que ocupam e usam territórios e recursos naturais como condição para sua reprodução cultural, social, religiosa, ancestral e econômica, utilizando conhecimentos, inovações e práticas gerados e transmitidos pela tradição. (Brasil, 2007)

Assim, segundo Prado (2012), a agricultura adquiriu novos significados e valores para os agricultores, seja a partir do contexto do direito à cidade ou da preservação e do desenvolvimento sustentável. 
Conhecido pelas culturas diversificadas da banana, caqui, chuchu, aipim, inhame e hortaliças, dentre outras, o Rio da Prata também se destaca pela peculiaridade de alguns de seus moradores - pessoas não alfabetizadas, residentes em casas de pau a pique, sem eletricidade e acesso à água encanada, e que fazem uso do fogão a lenha para o preparo do alimento. Tal particularidade da comunidade, somada à configuração geográfica, que lhe propiciou relativo isolamento, passa atualmente por um processo de valorização no mercado imobiliário, associado ao imaginário de um lugar bucólico e tranquilo. Condomínios destinados a grupos com poder aquisitivo diferenciado contrastam com as moradias de antigos residentes (Miranda, 2009). A concentração de sítios para a realização de festas e o aumento do número de bares e restaurantes, conferindo ao local o reconhecimento de polo gastronômico, também compõem a atual conformação socioespacial.

O Largo do Rio da Prata lembra uma pequena cidade do interior, com sua praça, a igrejinha de Nossa Senhora das Dores, coreto e bica (tombados em 1996), além de várias características rurais que coexistem com o meio mais urbanizado. Subindo a encosta, próximo às trilhas que dão acesso ao parque, localiza-se o Sítio Farol da Prata. Nesta propriedade privada, onde aos domingos é oferecido o "Café na Roça", também acontece a feira orgânica dos produtores locais, um minimercado com produtos naturais e, mais recentemente, uma feira de artesanatos.

De modo geral, as ofertas integram o universo em ascensão de um mercado de consumo mais natural. O cenário é complementado por animais "típicos da roça" (galinhas, patos e cabras) soltos entre os clientes ou presos por cordas. Atribuise à atratividade do local uma visão idílica e romanceada da vida rural, e é justamente onde verifica-se o aumento do fluxo de visitação e onde se concentra o início das atividades daqueles que vão ao PEPB. Desde o local, existem trilhas que atraem visitantes e turistas; mas são usadas principalmente por moradores e agricultores como meio de escoamento de seus produtos. Entre os principais atrativos estão pequenas cachoeiras e um jequitibá, uma árvore centenária.

Eventos e festas também contribuem para o imaginário criado. Anualmente, é realizado o "Tira Caqui", um mutirão de apoio para colheita, beneficiamento e comercialização do produto, organizado pela Rede Carioca de Agricultura Urbana. Neste evento, participam principalmente grupos e indivíduos vinculados a instituições de ensino e pesquisa, movimentos cujas pautas estão relacionadas a temáticas socioambientais e agroecológicas. É comum que estes eventos recebam algum tipo de apoio da gestão do PEPB, e passaram, então, a fazer parte do calendário do parque.

\section{b) Perfil da visitação}

Em relação ao perfil da visitação (Gráficos 1 a 17), a maioria dos visitantes é composta por adultos entre 26 e 50 anos (73\%), com Ensino Superior Completo (46\%). A média salarial é de três a nove salários mínimos - na qual 44.4\% dos visitantes recebem mensalmente entre 3 e 6 salários mínimos e 20.7\% recebem de 7 a 9 salários mínimos (Gráfico 3). A maioria dos entrevistados reside em Campo Grande (84\%), o que pode ser observado no Gráfico 4 e afirma ter como motivações principais para a visita o Café na Roça e a Feira de Orgânicos, como demonstrado no Gráfico 5. 
Gráfico 1 - Perfil de visitação: faixa etária

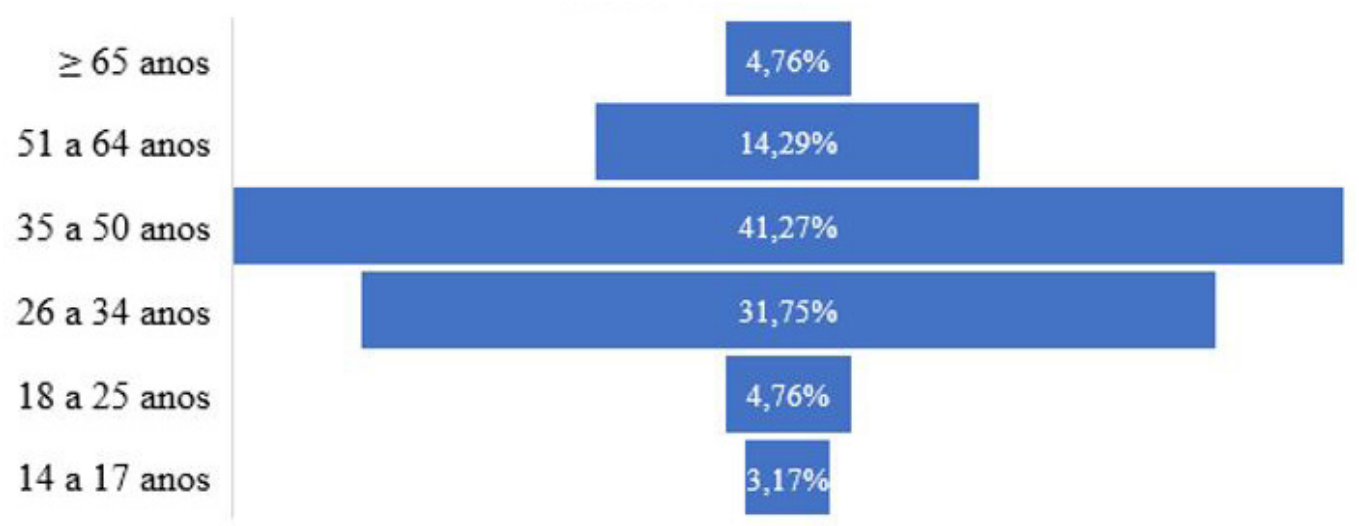

Fonte - Autores (2020)

Gráfico 2 - Perfil de visitação: grau de escolaridade

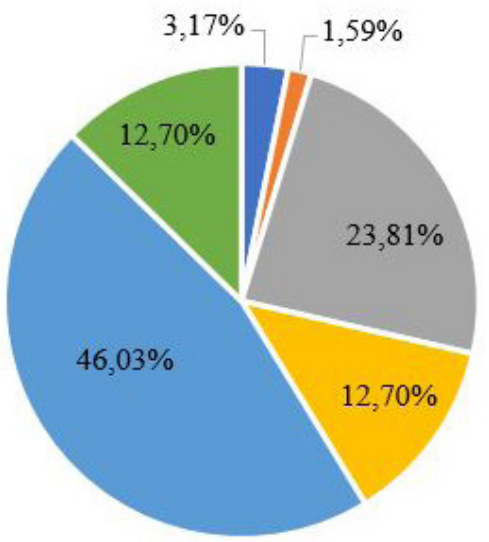

- Não alfabetizado

- Ensino Fundamental

- Ensino Médio

- Ensino Superior (incompleto)

- Ensino Superior (completo)

- Pós-Graduação

Fonte - Autores (2020)

Gráfico 3 - Perfil de visitação: faixa salarial

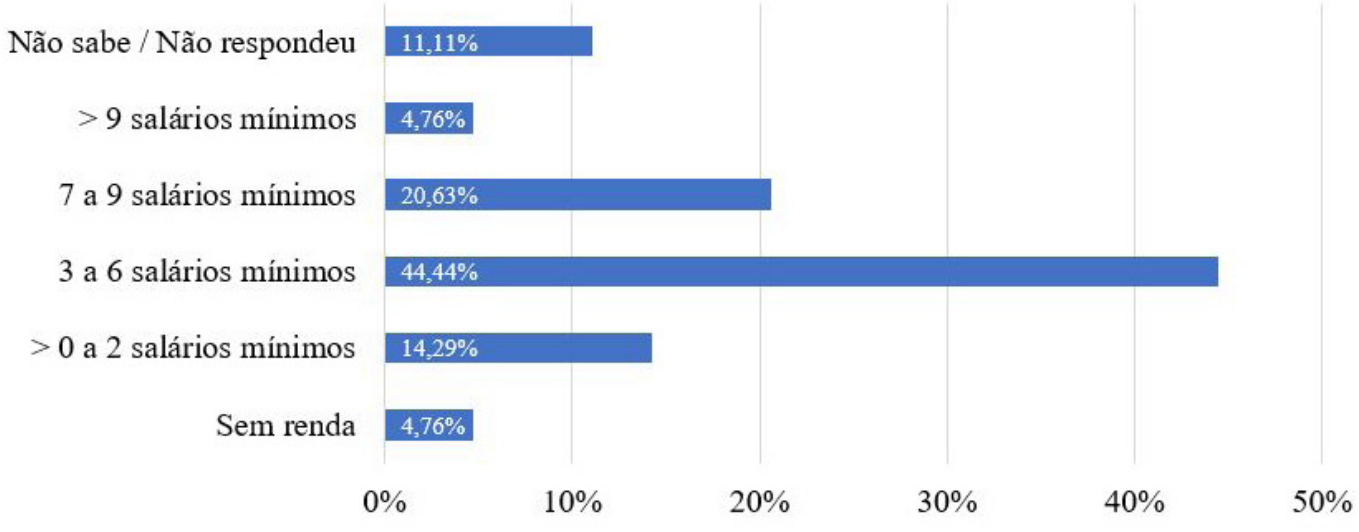

Fonte - Autores (2020) 
Gráfico 4 - Perfil de visitação: bairro de origem

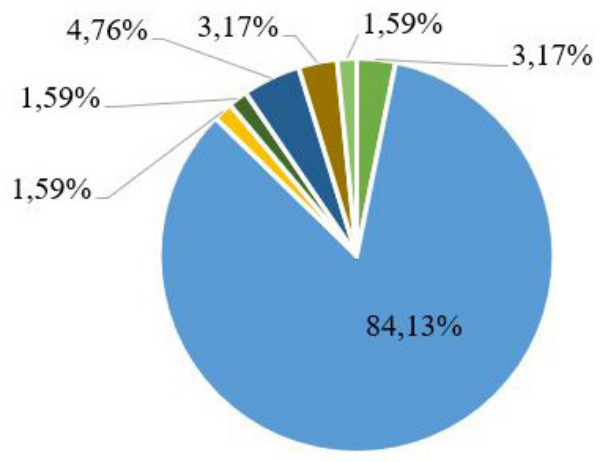

$$
\begin{aligned}
& \text { - Bangu } \\
& \text { - Campo Grande } \\
& \text { = Cosmos } \\
& \text { - Guadalupe } \\
& \text { - Niterói } \\
& \text { - Paciência } \\
& \text { - Rio da Prata }
\end{aligned}
$$

Fonte - Autores (2020)

Gráfico 5 - Perfil de visitação: motivação para o passeio

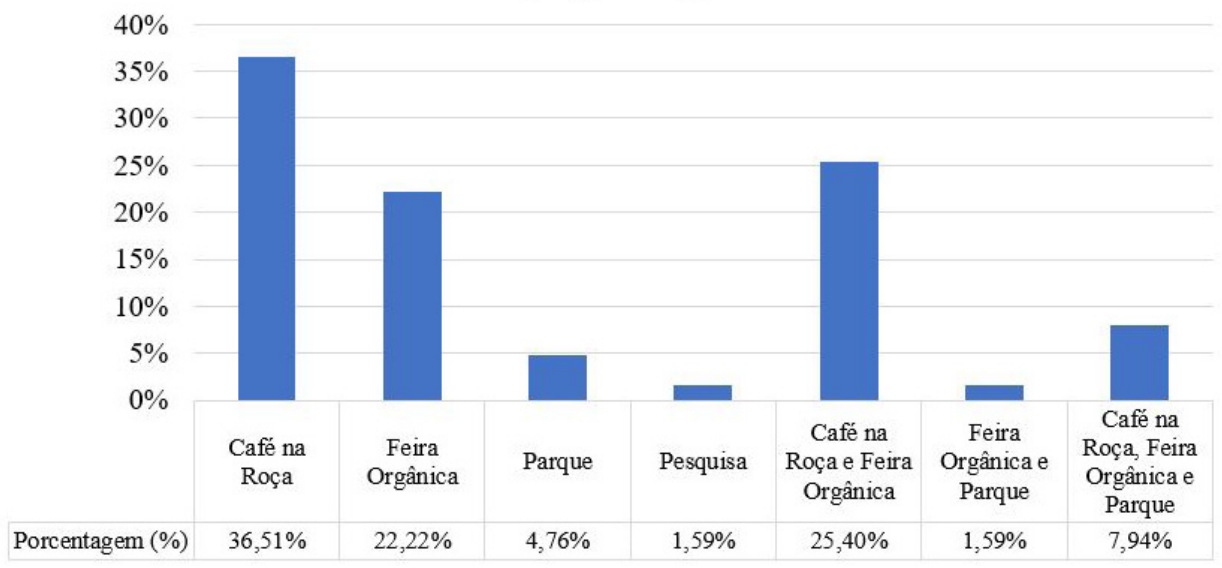

Fonte - Autores (2020)

Quando questionados se sabiam que estavam na área do PEPB, 40\% responderam que "não"; e 65\% disseram não ter conhecimentos sobre a comunidade e os agricultores do Rio da Prata (Gráfico 6). Tais resultados corroboram com outro dado apresentado adiante, no Gráfico 13, 60\% dos visitantes consideram regular ou ruim a divulgação de informações sobre a localidade.

\section{Gráfico 6 - Perfil de visitação: conhecimentos sobre a localidade}

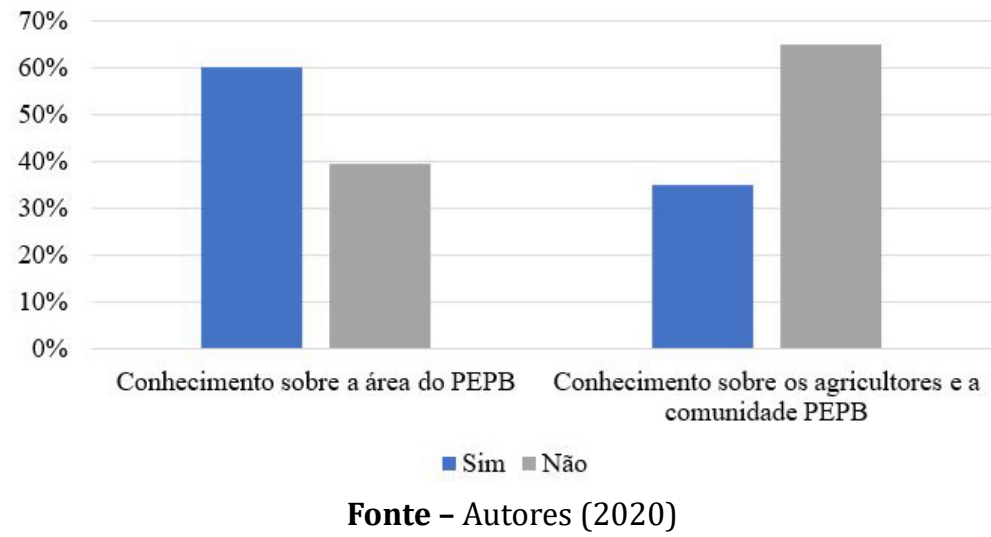


Oitenta e um por cento dos entrevistados disseram realizar o passeio em casal e/ou em família, como descrito no Gráfico 7. Em relação à assiduidade dos visitantes, revelada no Gráfico 8, 43\% dos entrevistados disseram estar no PEPB pela primeira vez, enquanto $21 \%$ foram mais de dez vezes ao local. 0 popular "boca a boca" parece ser o melhor meio de divulgação: 60\% dos entrevistados disseram saber do local por indicação, como registrado no Gráfico 9.

Gráfico 7 - Perfil de visitação: tipo de grupo

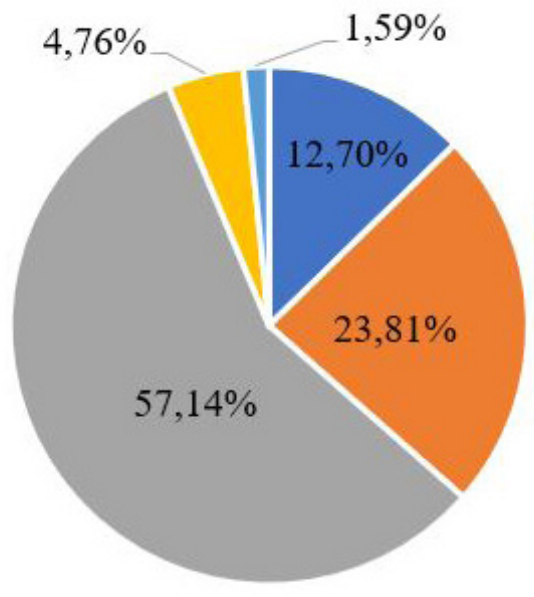

- Amigos $=$ Casal $=$ Família $=$ Sozinho " Não respondeu

Fonte - Autores (2020)

Gráfico 8 - Perfil de visitação: assiduidade

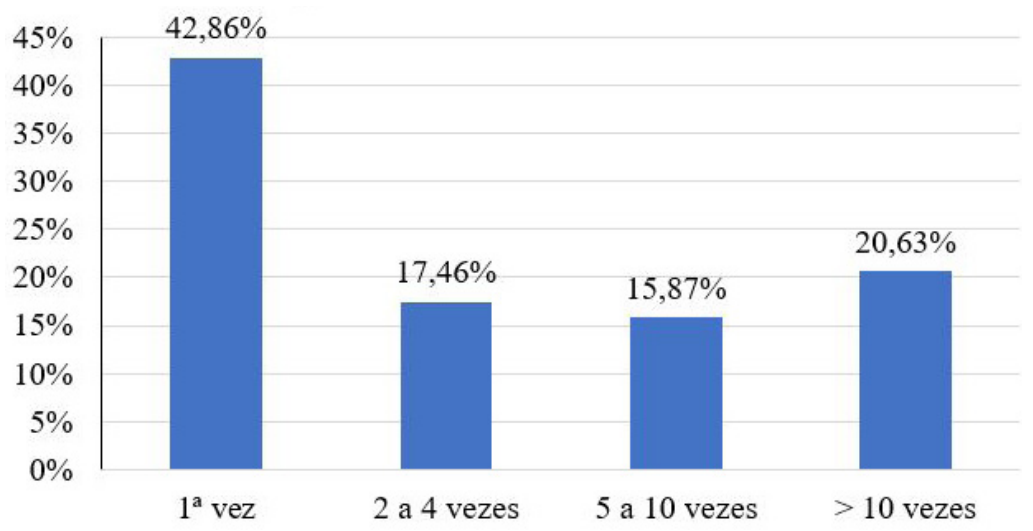

Fonte - Autores (2020) 
Gráfico 9 - Perfil de visitação: como soube do local

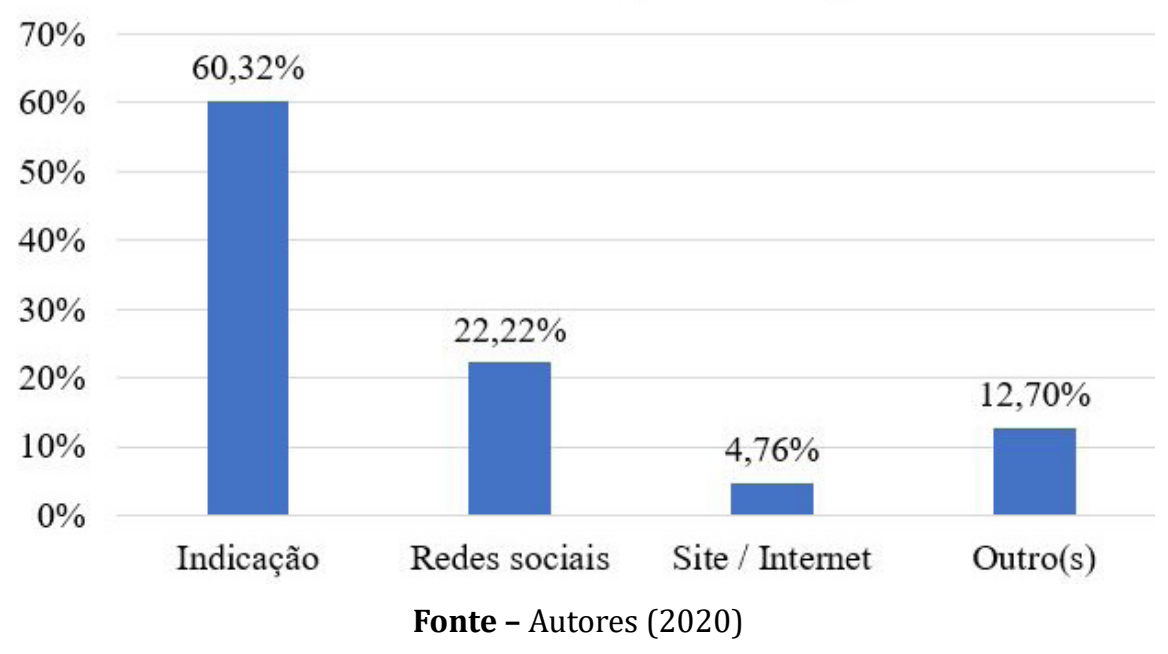

Quando questionados sobre as condições de acesso ao local, 70\% classificaram de forma positiva (Gráfico 13). Registrando-se que 92\% dos entrevistados utilizou carro particular para se deslocar até o Rio da Prata, como demonstra o Gráfico 10.

Gráfico 10 - Perfil de visitação: meio de transporte

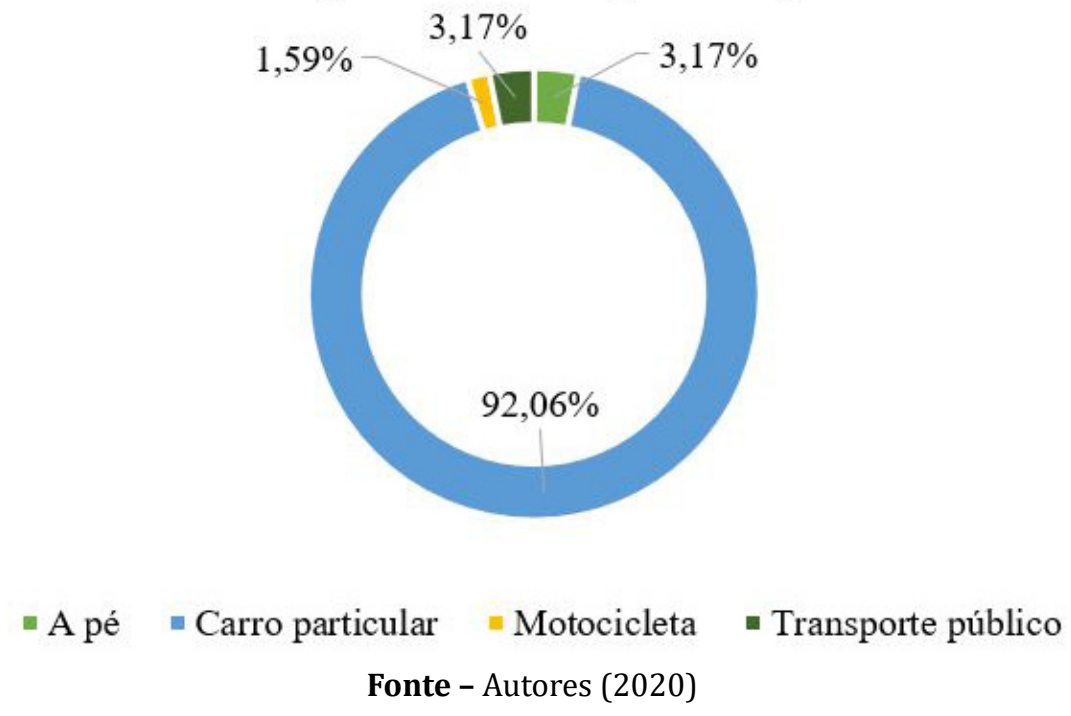

Conforme registrado no Gráfico 11, os serviços mais utilizados pelos visitantes são os de alimentação e estacionamento, mas também é significativa a compra de souvenirs e de produtos locais; havendo um gasto médio que varia entre R\$ 21 e R\$ 100 em produtos e serviços. Em relação a serviços que gostariam de utilizar, se disponíveis, os mais escolhidos foram circuito de experiência rural, atividade esportiva/aventura e contratação de guia/condutor, o que está apontado no Gráfico 12. 


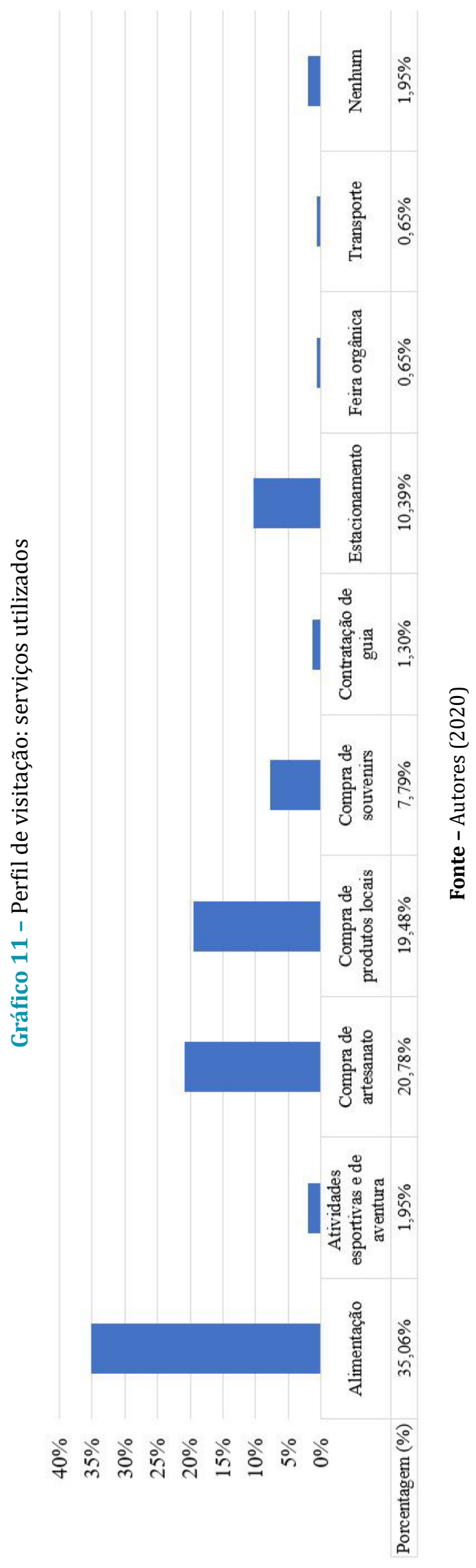


Gráfico 12 - Perfil de visitação: serviços desejados

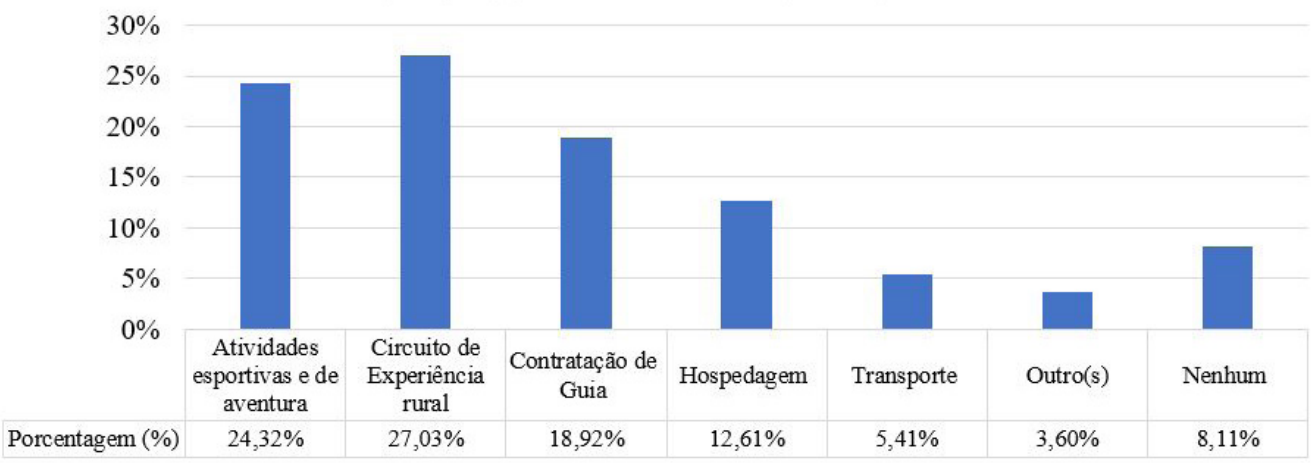

Fonte - Autores (2020)

No que tange à avaliação sobre o local, caracterizada no Gráfico 13, em relação às trilhas da região, 81\% disseram desconhecer e/ou não as ter utilizado; entretanto, 65\% classificam como "boa" a conservação dos recursos naturais e 18\% consideram "excelente". Na avaliação sobre o local, 75\% dos visitantes disseram ter suas expectativas completamente atendidas e $14.4 \%$ disseram ter suas expectativas superadas, como consta no Gráfico 14.

Também positivas foram as avaliações em relação aos atrativos locais (57.2\% classificaram como "bons"), à hospitalidade (58\% consideraram "boa" e $25.4 \%$ "excelente"), aos alimentos e bebidas oferecidos (60.3\% classificaram como "bons" e 22\% como "excelentes") e à segurança local (63.5\% consideraram "boa"). De modo que, quando questionados se voltariam ao local ou se indicariam aos amigos (Gráfico 15), 96,83\% responderam que "sim".

\section{Gráfico 13 - Perfil de visitação: avaliações}

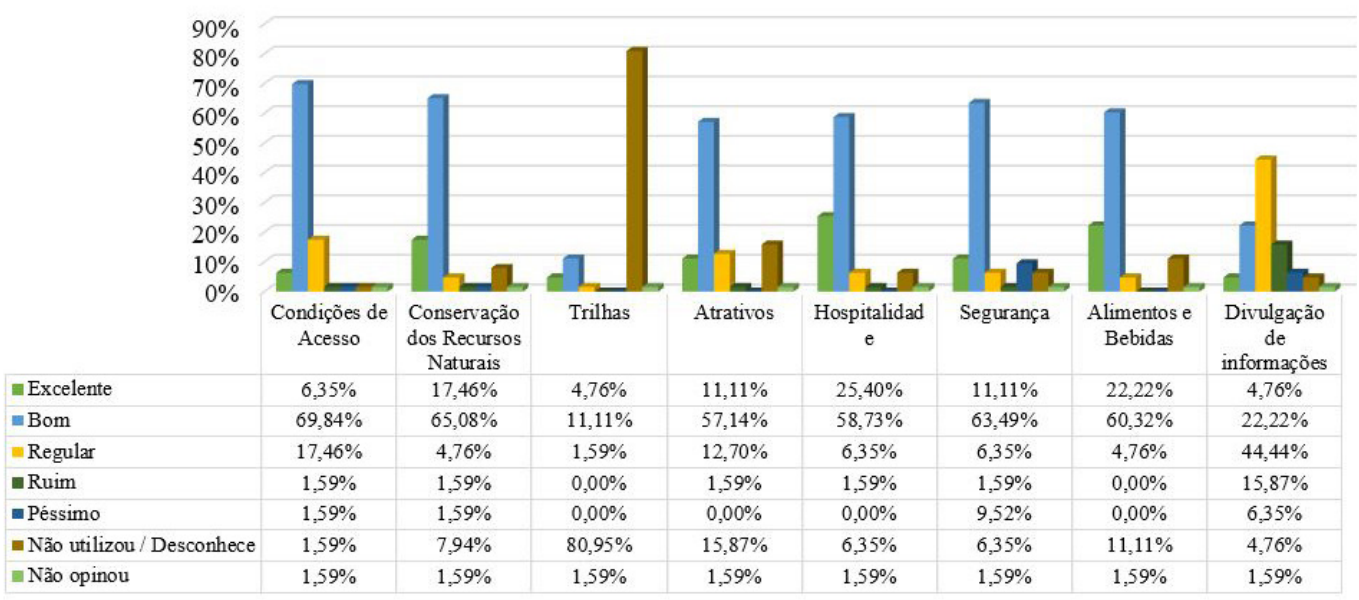

Fonte - Autores (2020)

Quase 50\% dos entrevistados disseram que pagariam uma taxa de visitação, se isso significasse manutenção ou melhoria da conservação dos recursos (Gráfico 16). Desses, 43\% pagariam $\mathrm{R} \$ 10,00$ e $36 \%$ pagariam $\mathrm{R} \$ 5,00$. 
Gráfico 14 - Perfil de visitação: expectativas

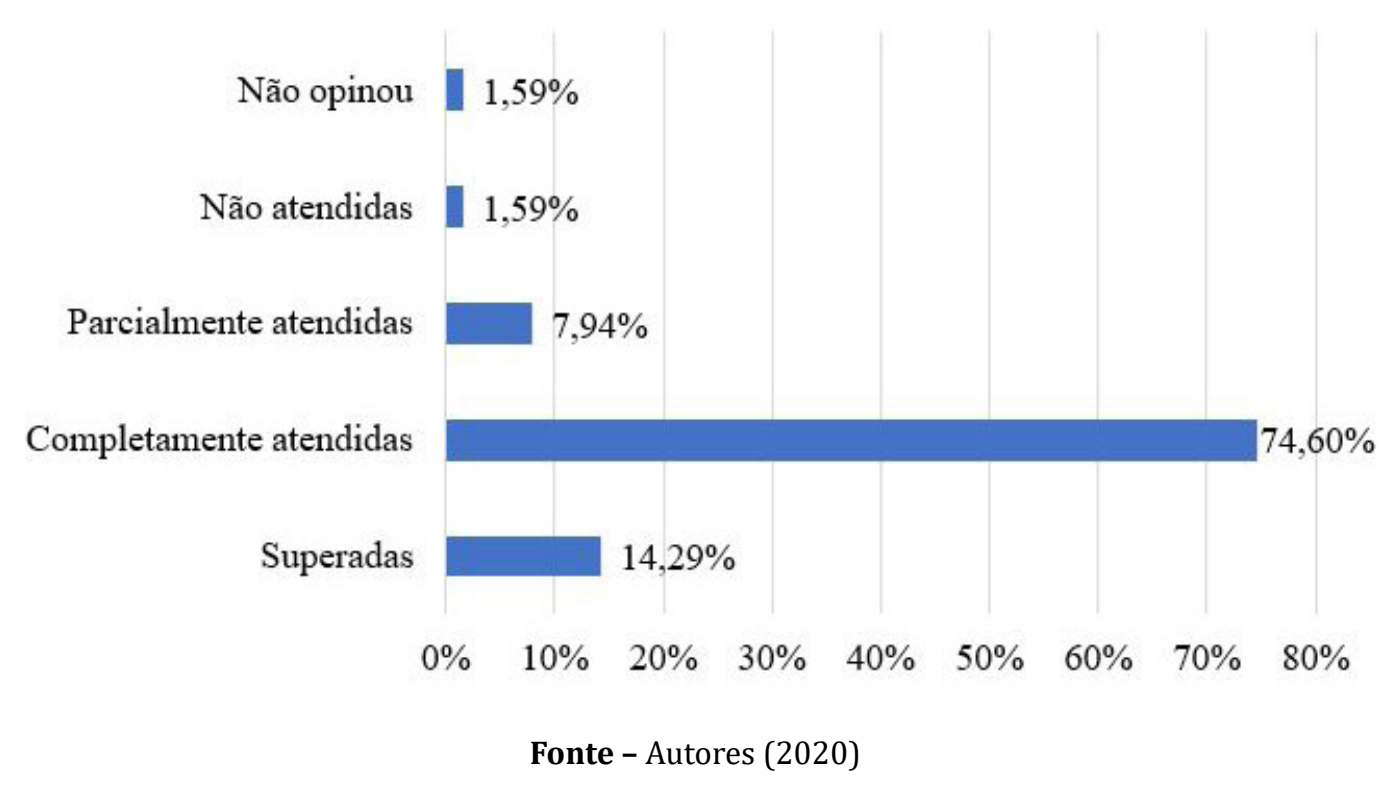

Gráfico 15 - Perfil de visitação: retorno e indicação
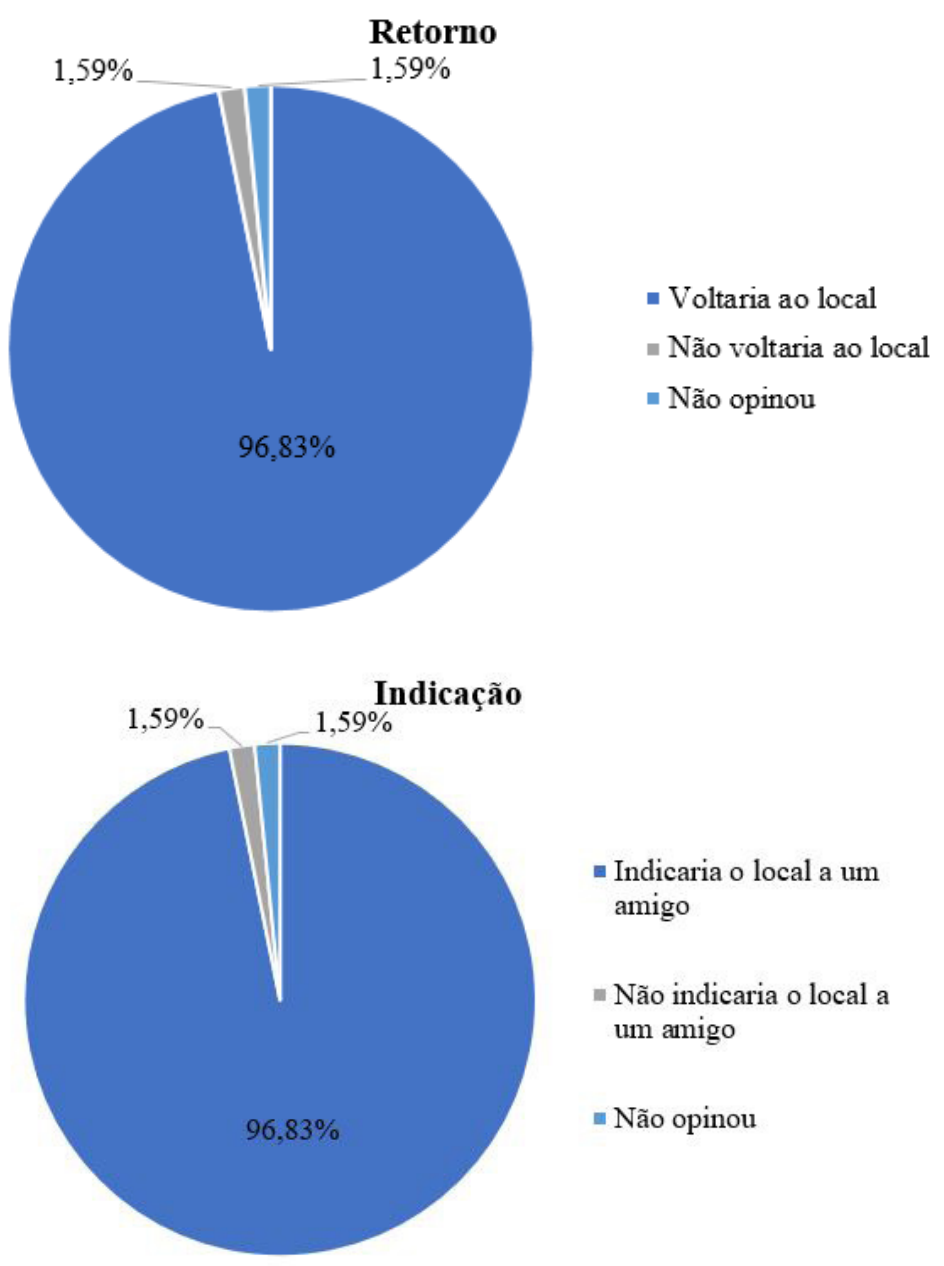

Fonte - Autores (2020) 
Gráfico 16 - Perfil de visitação: taxa

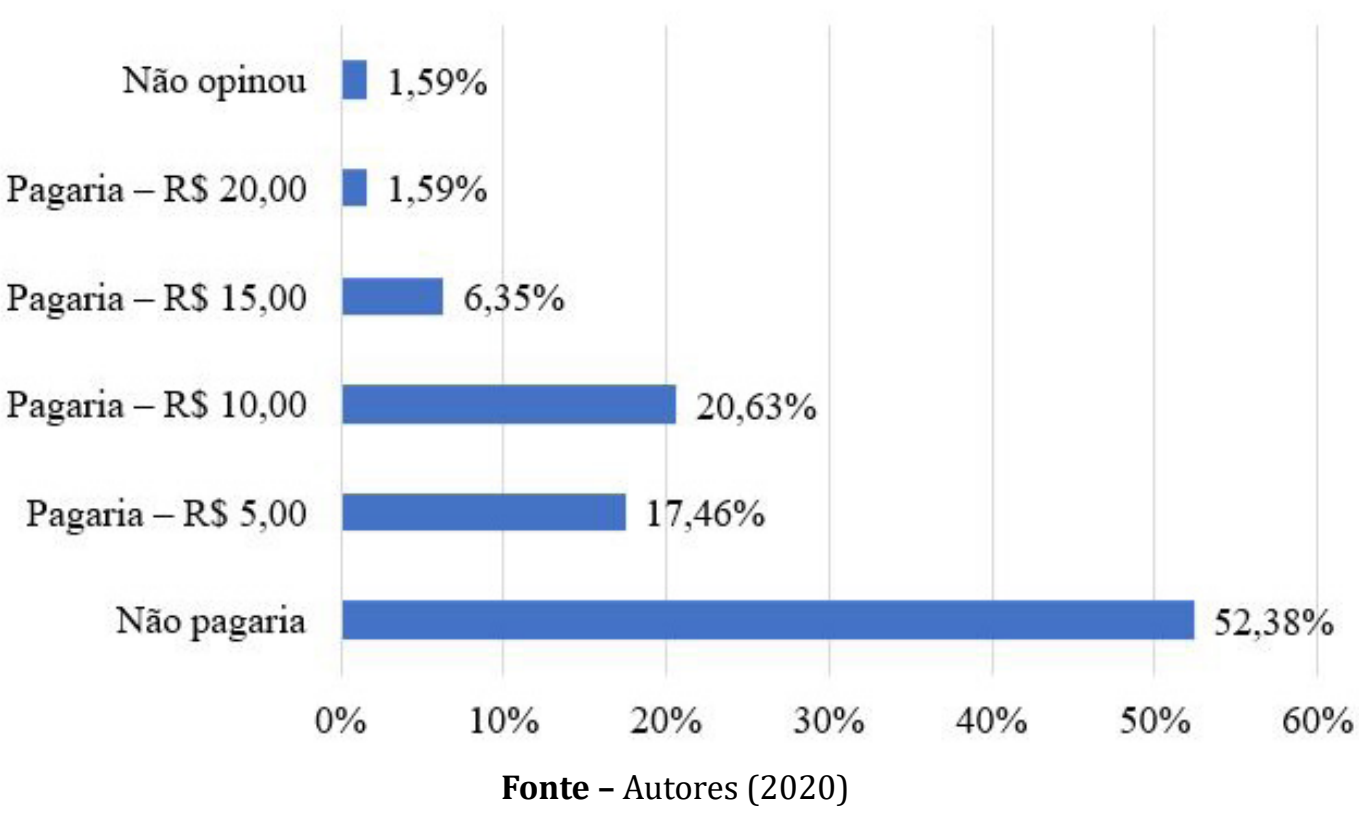

Em relação às informações que gostariam de receber sobre o parque/o local, os mais escolhidos foram atrativos naturais, história, e cultural local. Estas e as demais respostas estão apresentadas no Gráfico 17.

Gráfico 17 - Perfil de visitação: informações desejadas

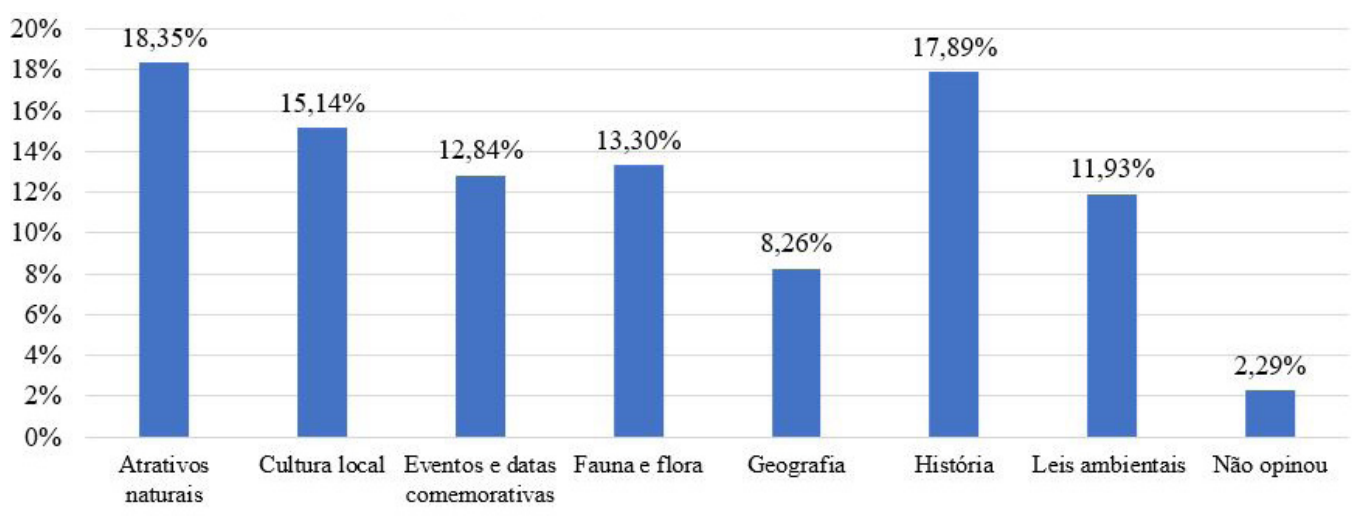

Fonte - Autores (2020)

Ao final do questionário, os entrevistados foram encorajados a deixar sugestões e/ou críticas a respeito da experiência de visitação. Algumas delas foram: a necessidade de ampliar a divulgação de informações sobre a localidade; realizar melhorias na sinalização de acesso e indicações das trilhas; oferecer mais opções de lazer em meio à natureza; trilhas com guia ou condutores; promover mais eventos sobre cultura e história local; e promover a expansão da feira de orgânicos e o estímulo à educação ambiental por meio de cursos e workshops. 


\section{c) Questionário com condutores locais}

0 questionário foi respondido por $42 \%$ dos formados pelo Curso de Condutor de Visitantes do PEPB. E as percepções foram, em geral, positivas. Isto, pois, 93\% dos entrevistados disseram estar muito ou extremamente satisfeitos com o curso imediatamente após sua conclusão (Gráfico 18).

Entretanto, quase dois anos após o encerramento das aulas, apenas 54\% estavam muito ou extremamente satisfeitos, enquanto $46 \%$ declararam pouca ou nenhuma satisfação. 0 aumento da insatisfação foi justificado por meio de uma pergunta aberta, na qual destacaram a necessidade de "atualização" e "reciclagem", além de maior apoio e integração do INEA na provisão de visibilidade e reconhecimento aos condutores locais. Resultados no Gráfico 18.

Gráfico 18 - Curso de condutores: índice de satisfação

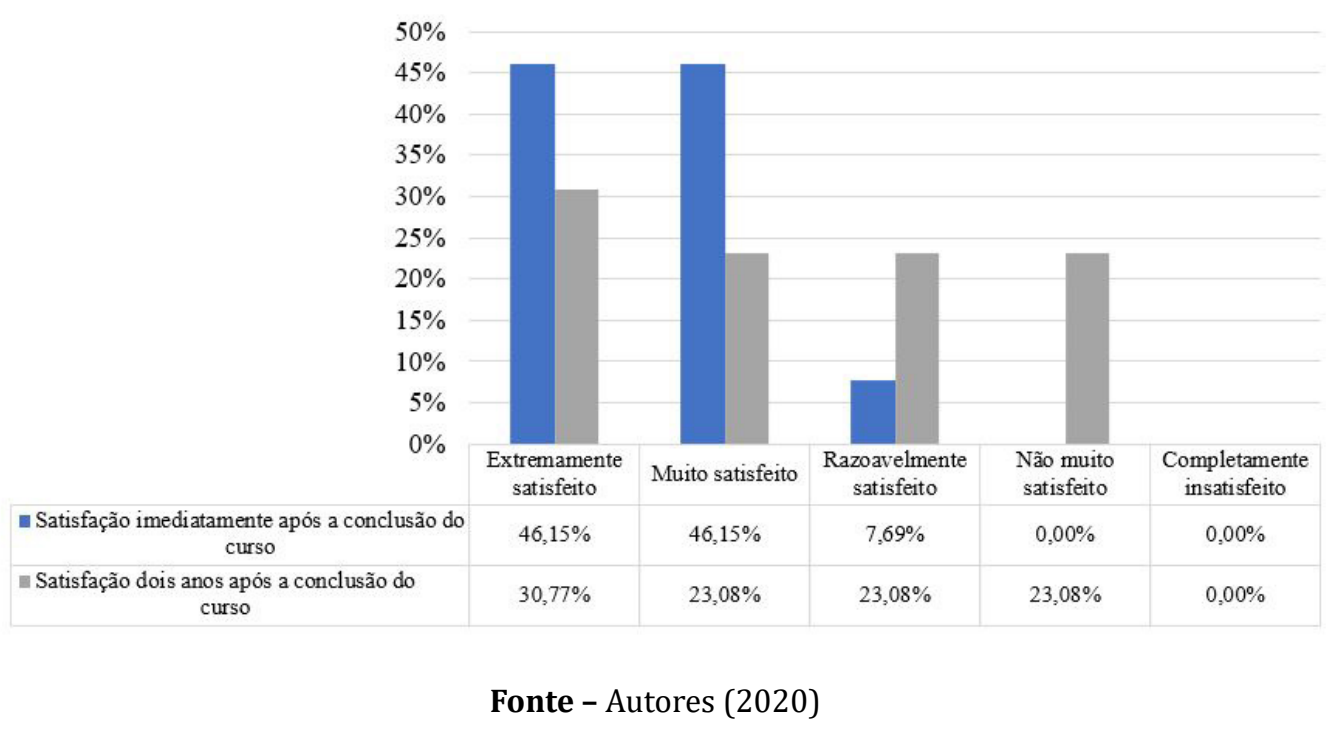

Gráfico 19 - Curso de condutores: motivos de insatisfação

- Ausência de apoio por parte do INEA após o curso

- Falta de continuidade e/ou atualização

- Renovação das credenciais

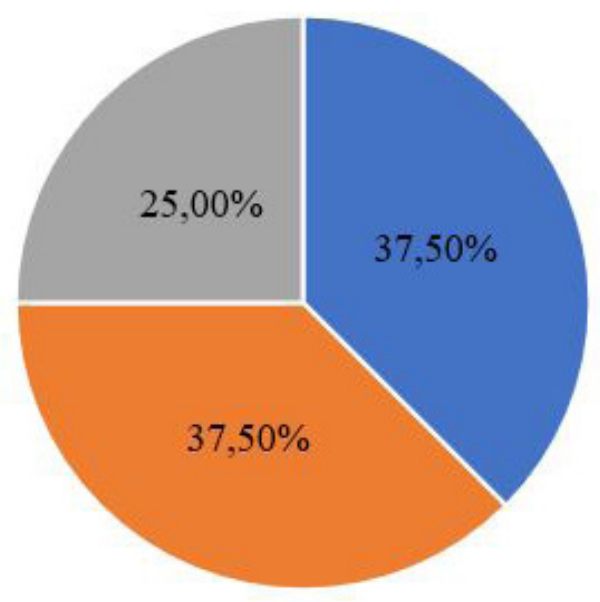

Fonte - Autores (2020) 
Quanto aos pontos positivos do curso, descritos no Gráfico 20, os mais mencionados, em ordem decrescente, foram: qualidade dos instrutores e conhecimento adquirido; conjunto de amizades e conexões; trabalho de campo; e satisfação pessoal. Quanto aos pontos negativos (Gráfico 21) necessidade de mais trabalho de campo; duração reduzida do curso; deslocamento; e logística.

Gráfico 20 - Curso de condutores: pontos positivos

Relações de afeto desenvolvidas ao longo das aulas

Instrutores qualificados

Conteúdo teórico

Aulas práticas

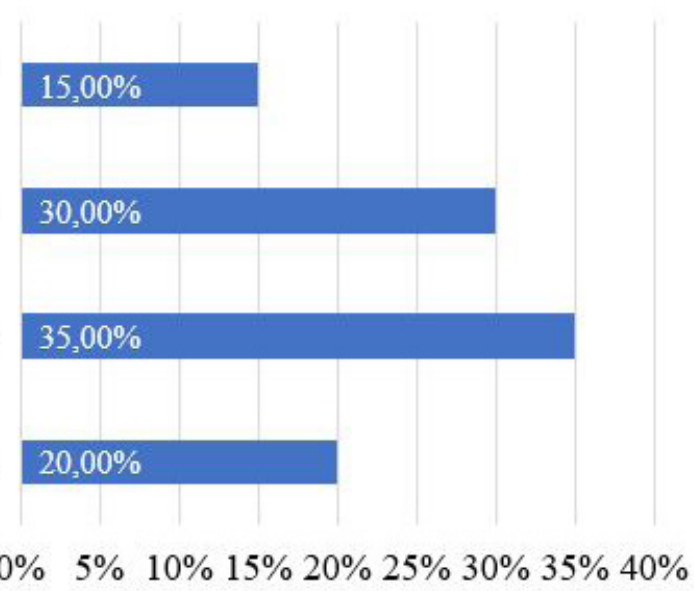

Fonte: Autores (2020)

Gráfico 21 - Curso de condutores: pontos negativos

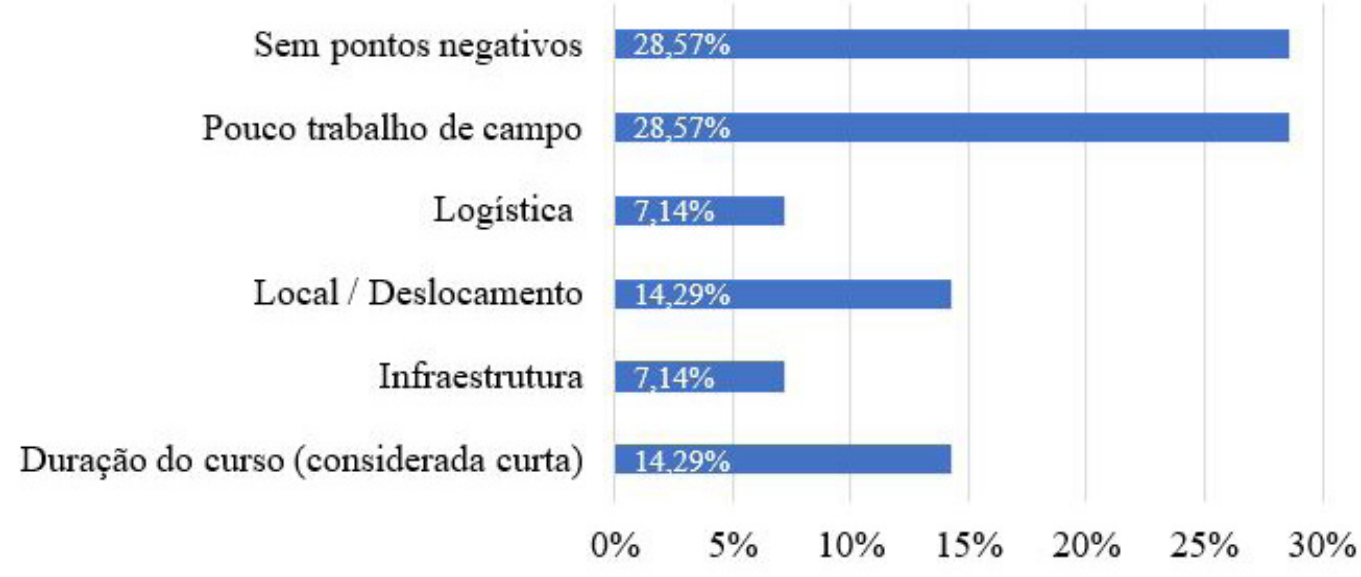

Fonte - Autores (2020)

Sobre as oportunidades de emprego que surgiram após o curso, 30,8\% disseram estar muito ou parcialmente satisfeitos, $46,2 \%$ razoavelmente satisfeitos, e $23 \%$ completamente insatisfeitos ou pouco satisfeitos. Tais informações constam no Gráfico 22.

Em relação ao grupo de entrevistados, 38,5\% disseram que já trabalhavam como condutores locais no PEPB antes do curso. Após a capacitação, 15,5\% a mais começaram a fazê-lo, principalmente orientando turistas e estudantes de instituições de ensino, como consta no Gráfico 23. 
Gráfico 22 - Curso de condutores: oportunidades profissionais

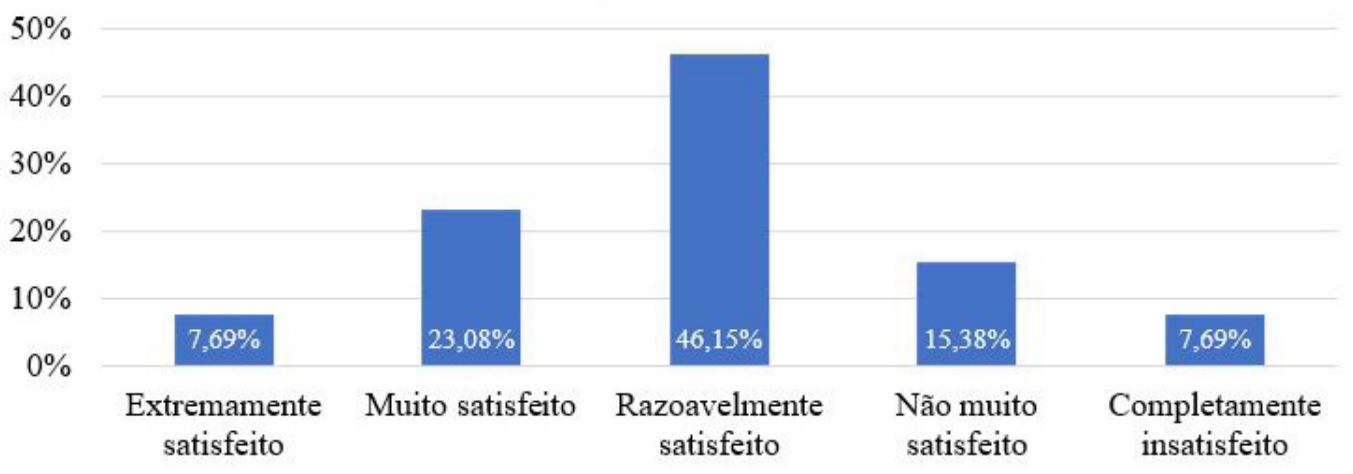

Fonte - Autores (2020)

Gráfico 23 - Curso de condutores: condução de visitantes

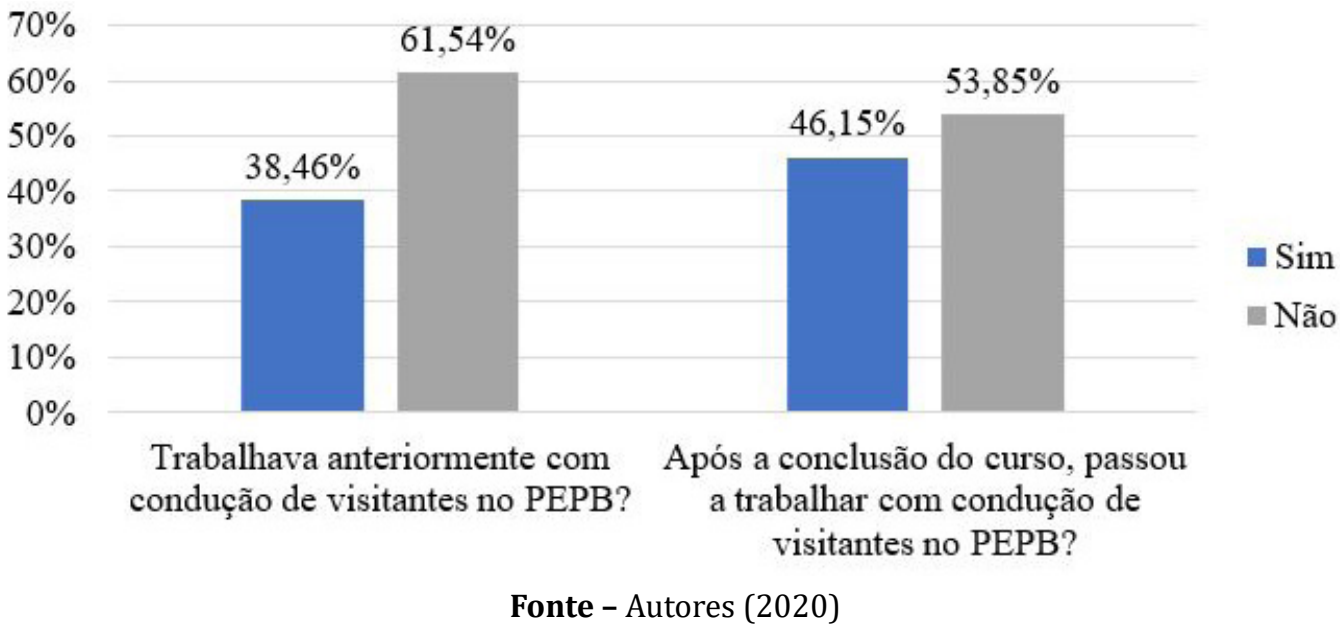

Todos responderam que o curso os fez entender mais sobre as UC e sobre o PEPB. E que os ajudou na vida profissional e/ou pessoal.

\section{d) Entrevistas}

As entrevistas foram amplas e aprofundadas. Permitiram captar a compreensão dos entrevistados sobre o que estava acontecendo no local e revelando elementos importantes para entender a turismização na região, bem como as expectativas e frustrações em torno disso. Pareceu unânime a percepção sobre o aumento de fluxo de pessoas, induzido ou não pelo PEPB.

É notável, também, o desejo por um tipo de visitação que resulte em reconhecimento e valorização de suas práticas, modos de vida e empreendimentos, que estão associados ao natural/rural. A relação e integração entre INEA e os moradores, a concepção de turismo, o curso de condutores e a Trilha Transcarioca foram temas que surgiram em todas as entrevistas. Visando permitir maior fluência e expressão oral dos entrevistados, as entrevistas não foram estruturadas. Assim, os resultados são apresentados ao longo da discussão a seguir. 


\section{DISCUSSÃo}

\section{Representações do turismo}

A perspectiva teórica que orienta este trabalho insere-se nos estudos de turismo não apenas como negócio, mas também como processo cultural enquadrado na turismização conforme argumenta Mendonça (2010). Retomamos o pensamento de Tribe (1997) e apresentamos concepções de turismo a partir do entendimento dos entrevistados.

Para Pereiro e Fernandes (2018), os imaginários turísticos são construções sociais passíveis de revelar como agentes sociais pensam, organizam e estruturam suas visões de mundo acerca do fenômeno turístico. As construções sociais a que se referem são elaborações simbólicas resultantes de processos constituídos a partir das representações sociais (Horochovski, 2004) e, no caso em estudo, estas são pessoas que estabeleceram relações constituídas a partir de "universos" distintos. Assim, produziram e/ou estão produzindo trocas de conhecimentos e transferências de saberes. E os intercâmbios manifestados podem ser interpretados como ações orientadas a partir de distintos interesses que configuram o imaginário sobre o turismo no local.

Para organizar as ideias de representações do turismo, identificamos nas respostas: o que é turismo para eles, como eles veem esse turismo que está acontecendo, e o que mudou ou deveria mudar na comunidade com o turismo que está ocorrendo. As respostas permitiram aferir concepções que distintos atores envolvidos no processo de turismização em curso no Rio da Prata de Campo detêm sobre turismo.

\section{Educação formal e não-formal}

A concepção sobre turismo está assentada na percepção de que este é externo ao grupo, sendo uma proposição do poder público manifestada em outra ordem de significados aos anteriormente existentes, pois como relatado por E.: “[...] o turismo não vem de hoje lá. Já no final do século passado, tinha turismo, as pessoas já atravessavam [...], basta ver os jornais antigos.... Em tal concepção, E. aponta para um turismo relacionado a lazer, diversão e mobilidade de pessoas, que "atravessavam" a região. Nesta lógica, turismo seria algo comum no local, sendo cotidiano aos moradores e pessoas do entorno, que realizavam atividades recreativas no espaço onde hoje está compreendida a vertente do Rio da Prata. 0 turismo que agora desponta neste espaço seria algo externo àquela localidade e que transformaria um espaço ordinário em extraordinário.

\section{Prestação de serviços turísticos}

As respostas revelam que há iniciativas de utilização do que é entendido como turismo por alguns empreendedores locais. Estes perceberam o crescimento de uma demanda que difere da habitual e, a partir dessa constatação, refletem uma concepção de turismo como oportunidade de geração ou ampliação de renda e também como estratégia de salvaguarda de outros valores, como a agricultura que, em última instância, é o que lhes garante a propriedade da terra e a sobrevivência financeira de parte dos moradores do PEPB. Daí a afirmativa de A.: "turismo não é necessário porque o que protege é a agricultura". 
Se, por um lado, na concepção destes empreendedores, o turismo não é necessário, a agricultura e, mais precisamente, o esfacelamento desta, é algo que torna o local atrativo. Nesta perspectiva, vemos o acionamento do imaginário acerca do turismo enquanto salvador de economias em decadência.

Paralelamente, P. considera o turismo como algo que não é espontâneo, pois a "região está sendo direcionada para o turismo" - que ali está introduzido de forma a valorizar aspectos que este grupo parece discordar. Ou seja, a ênfase nos aspectos cênicos e naturais que particularizam os imaginários dos parques (Fernandez, 2016).

Em tal contexto, estes empreendedores locais - que veem o turismo como uma possiblidade de salvação econômica e garantia de permanência local consideram que empreender em turismo é também buscar a distinção por um produto, como mencionado por P. "[...] se vê fazenda de café, de uva, fazendo turismo... porque a gente não pode fazer com a nossa produção de caqui?”. Mas, na impossibilidade deste uso extensivo, por se tratar de uma UC, a estratégia destes empreendedores incide na divulgação e reafirmação de uma identidade associada ao rural e tradicional. Ou, conforme fala corrente na localidade, ao que é "da roça".

Não por acaso, P. menciona: "[...] eu recebo num final de semana 400, 450 pessoas para o café da manhã na roça e pode-se dizer que $10 \%$ são as que fazem caminhada, mas não conhece o modo de viver deles, muito menos sua cultura...". Pelo exposto, os prestadores de serviço estão destacando que o turismo que lá ocorre é o que se insere na mais elementar forma de apresentação da alteridade (Pereiro \& Fernandes, 2018). Ou seja, os hábitos e sistemas alimentares que particularizam os grupos culturais - e não o turismo idealizado pelo poder público, por ter esse desconsiderado a cultura de um povo tradicional.

\section{Associação de Agricultores Orgânicos}

A análise resultante da entrevista com A. se assemelha à de P., pois evidencia que o turismo induzido pelo INEA não atende ao que desejam e desconsidera as iniciativas voltadas para apresentar aos visitantes o que julgam importante. Nota-se a busca pela reafirmação de uma identidade cultural associada à ideia de proteção e salvaguarda de valores e recursos hoje considerados relevantes para toda a sociedade, mas que coube à cultura daquele grupo através de suas práticas e formas de se relacionar com a terra, o que hoje é interpretado como turístico. Para o entrevistado, a história e a cultura dos pequenos agricultores do local são indissociáveis da configuração cênica e dos atrativos naturais divulgados pelo poder público.

\section{Órgão público responsável pela gestão do UP do PEPB}

A análise aqui realizada recai sobre as noções que o INEA produz sobre turismo. 0 conjunto de respostas remete à concepção de que o turismo não é algo que se manifesta espontaneamente - devendo ser induzido, domado e enquadrado em determinado padrão, onde caberia ao poder público a obrigação de tutelá-lo. A despeito de tal visão, é possível perceber brechas passíveis de agregar à análise aqui em curso, a noção de parceria, pois este termo foi repetido em distintos momentos nas falas dos entrevistados, se referindo a associações já instituídas com moradores e atuais e/ou potenciais prestadores de serviço. 


\section{Principais desafios e potencialidades relacionados ao turismo}

O material coletado permitiu identificar oportunidades e desafios associados ao turismo pelo olhar dos consultados. No questionário aplicado aos visitantes, $70 \%$ classificaram como boas as condições de acesso local. Considera-se que isso se dá em efeito comparativo a outros locais que buscam oferecer experiências associadas ao rural/natural. 0 Sítio Farol da Prata está a cerca de $5 \mathrm{Km}$ do centro de Campo Grande. E todo o percurso é asfaltado. Além disso, há a possibilidade do uso do transporte público.

Em relação às trilhas da região, a maioria dos entrevistados disse desconhecer e/ou não as ter utilizado. Considera-se que ter em vista esse público parece ser oportuno não só para possíveis prestadores de serviços, mas também para os gestores do PEPB. Dado, inclusive, o potencial de pessoas dispostas a pagar uma taxa de visitação.

Elementos como hospitalidade, alimentos e bebidas, e segurança foram associados à alta satisfação dos visitantes. Deste modo, a maioria disse ter suas expectativas atendidas, E que voltaria ao local ou indicaria aos amigos.

As entrevistas e questionários indicam possibilidades de atividades que complementariam a "oferta de experiência". E apontam como potencialidade os agricultores da região, suas habitações e dinâmica de vida, o que pode ser observado nos trechos transcritos a seguir:

Tem muito sitio interessante na comunidade [...]. Tem gente que tem nascente dentro de casa, tem algumas coisas. [...] eu acho que mostrar essa coisa rústica, o que a comunidade é verdadeiramente... É um lugar rústico, as pessoas têm uma vivência: o que é que vive, como vive. Essa pessoa mesmo, morador lá do morro, o que ele faz no dia a dia? Eu acho que isso é o interessante. (E.).

E. destaca ainda que o turismo, associado à dinâmica de vida dos agricultores orgânicos, parece ser benéfico não só para visitantes, mas também para que a comunidade valorize o trabalho dos produtores:

Seu fazer é importante e tem muito potencial turístico, né? Mas é seu próprio fazer, não é algo diferente, não é você 'oh, vamos fazer pirueta pra vir gente ver nossa pirueta'. Não é isso, é o seu próprio fazer, é um potencial turístico, eu acho que é isso. (E.).

Isso também se apresentou como um desejo dos visitantes em relação às informações que gostariam de receber, destacando-se os atrativos naturais, a história e a cultura local. Da mesma forma, o circuito de experiência rural poderia ter forte aderência por parte do público que já visita o local.

Conforme exposto, P. acha que o turismo deveria ser encarado como um substituto da atividade agrícola, que apesar de ter sido mais valorizada recentemente, irá perder espaço para grandes produtores. Para P., deveria haver um investimento nos jovens e filhos de agricultores para que empreendessem no setor de turismo, conciliando com a valorização dos remanescentes naturais e práticas 
agrícolas de suas famílias. 0 entrevistado destaca ainda atrativos a possibilidade do caqui se consolidar como um símbolo da região.

A ideia de valorizar o caqui como um atrativo, vinculando-o como um signo e tendo sua qualidade associada ao imaginário do local, é interessante não apenas sob o ponto de vista econômico, mas também como um dos elementos de afirmação identitária (como detentores de uma cultura agrícola e rural). Sua produção pode ser vinculada também ao valor paisagístico do local.

Apesar de discordar de P. por considerar o turismo como algo "infelizmente inevitável", A. parece ter uma visão similar à de E. sobre o que seria um turismo "ideal", em que agricultores pudessem conciliar com suas atividades rotineiras, e ser valorizados "pelo seu saber fazer". A. indica que há uma iniciativa em desenvolvimento nesta configuração, em que produtores recebem visitantes, que "vivenciam" o seu dia a dia na roça, e podem comprar produtos orgânicos diretamente de quem produz. Para A., esse tipo de iniciativa contribuiria também para que a comunidade pudesse contar a sua história, e que fosse reconhecida como agente de preservação.

A. reforça a hipótese de que o turismo pode ser mais uma ferramenta para a manutenção do pacto ambiental, iniciado a partir da requalificação social em decorrência da "conversão" (Leal, 2010) para a produção orgânica. Além disso, pode reiterar o caráter "tradicional" da comunidade. A. também menciona a ideia de roteiros que explorem o viés afetivo da alimentação, e relata sobre a existência de elementos materiais que poderiam compor um "Museu do Agricultor".

É interessante constatar que o INEA parece ter uma ideia que pode não estar alinhada à expectativa manifestada por A., e sim com P. Isto, pois, mencionam a necessidade de "uma marca que mostre interação do parque com a comunidade. Ter selos, parcerias e qualificações”.

No que tange à Trilha Transcarioca, P. considera como positivo, já que sua implementação "aumentou o fluxo de visitantes dentro da região". Por outro lado, A. se diz "contra" a Transcarioca. Isso parece estar relacionado ao fato de a trilha atrair um tipo de visitante que não necessariamente estará interessado em elementos que a comunidade deseja valorizar a partir do turismo, ou seja, história e práticas agrícolas locais.

Críticas à trilha estão relacionadas também à falta de recursos destinados ao ordenamento do UP. Além disso, há, por parte de alguns moradores, o entendimento de que a trilha é "um projeto de turismo" com uma abordagem "de cima para baixo". E, assim, não se sentem contemplados. A partir de conversas informais durante o trabalho de campo e a participação em eventos e reuniões, foi percebida como notória a insatisfação por parte de moradores quanto ao desempenho de fiscalização e ordenamento do UP. Queixas sobre ações de motocross, supressão de vegetação e outras práticas ilegais são corriqueiras e afetam as percepções e expectativas sobre o turismo; o que foi constatado também nas entrevistas.

São diferentes as formas como cada entrevistado parece entender os "tipos" de turismo possíveis e em curso - bem como as expectativas relacionadas à atividade. Também divergem no modo como interpretam o apoio prestado pelo INEA a algumas iniciativas; o que acarreta certa "tensão" quando abordados determinados temas. De todo modo, é unanime a percepção de uma comunidade "desconfiada" e "conservadora" em relação ao turismo, em virtude, principalmente, do histórico conflituoso com o INEA, o que destacamos como um dos desafios. 
Unanime também é a percepção sobre a necessidade de maior atenção à juventude da comunidade no que diz respeito às oportunidades de trabalho associadas aos atributos do local. Isto se dá em um cenário em que muitos adolescentes e jovens, filhos de agricultores, inseridos em um contexto de oportunidades laborais limitadas, não parecem desejar seguir desempenhando o trabalho agrícola. Assim, todos os entrevistados expressaram desejo de qualificações e outros tipos de ação formativa ou educativa, que possam instigar às novas gerações quanto as possibilidades de empreender a partir da crescente valorização do local.

$O$ INEA parece perceber essa demanda. E acrescenta outro desafio relacionado à região, que, caso superado, pode contribuir para o cumprimento de alguns dos seus potenciais: "Precisamos avançar nos acordos ${ }^{5}$ e na capacitação dos agricultores. Um ator importante para o Rio da Prata é a Secretaria de Agricultura, que tem desenvolvido projetos voltados para o turismo rural". Assim, reconhece a ausência de integração com outros setores e órgãos públicos na indução do turismo no local, bem como no seu planejamento e gerenciamento.

\section{Curso de condutores}

Questionados sobre a satisfação do INEA em relação aos resultados do Curso de Condutor de Visitantes, os técnicos entrevistados demonstraram uma visão positiva sobre a experiência. Segundo eles, as expectativas do órgão foram atendidas, uma vez que a capacitação gerou "maior aproximação da comunidade com o parque", bem como melhorias na qualidade das visitações, tornando a atividade mais segura para os visitantes. Também foi apontado que, além da qualificação de mão de obra, a realização do curso teria aberto "um canal de diálogo com as UC".

Entretanto, contrastamos essa visão com a mudança do índice de satisfação dos condutores em relação às oportunidades de trabalho, passados dois anos da conclusão do curso. A qualificação visava torná-los aptos a atuar como condutores locais, de forma autônoma; mas a participação no curso não garantia um posto de trabalho. Tampouco era garantia de exclusividade, uma vez que o parque não tem como impedir que os visitantes contratem outros condutores não cadastrados e guias de turismo.

Entre as causas apontadas para a mudança de percepção sobre o curso, foram mencionadas a falta de continuidade e a necessidade de "reciclagem". O que poderia garantir a renovação das credenciais concedidas pelo INEA após o curso.

Observa-se um descontentamento em relação ao órgão: “[...] o quase desligamento do INEA depois do curso. Não tem fluxo de clientes indicados, falta apoio de segurança para o guiamento". E, também, “[...] poderia ter dado mais apoio depois que acabou o curso; como, por exemplo, uniforme, parcerias com agências de turismo, escolas e universidades, para nós podermos trabalhar." Esses relatos não corroboram com a percepção de P. e com o interesse dos visitantes.

Apesar de 19\% dos condutores formados serem do Rio da Prata e proximidades, P. relata que encontra dificuldade em manter uma equipe de condutores com disponibilidade para atender à demanda de visitação do "Café da Roça".

5. Refere-se ao Termo de Compromisso e outros documentos que viabilizariam melhor entendimento e segurança entre as partes. 
Já os visitantes mostraram expressivo interesse em contratar serviço de guiamento/condução local, caso fosse ofertado.

De todo modo, é unânime a percepção de que o curso contribuiu para o desenvolvimento profissional e pessoal dos condutores, sendo mencionado o desenvolvimento de posturas de maior responsabilidade e conscientização socioambiental. E. e A. mencionam um possível mau aproveitamento do curso. E. diz perceber "um turismo de exploração de um espaço e ponto", e identifica o turismo local como uma atividade que não apresenta uma verdadeira integração com a comunidade.

A. relata que, apesar da intenção do INEA de qualificar a mão de obra local, o curso deveria ter adotado uma "linguagem acessível". Segundo o entrevistado, isso possibilitaria maior aproximação da comunidade, pois "[...] o curso não foi preparado para quem não tinha certo grau de instrução. [...] então, alguns que começaram desistia porque não conseguia acompanhar". Recomendamos, portanto, que futuras qualificações ofertadas pelo INEA considerem: abordagens que atraiam e contemplem os jovens da região, que sejam disponibilizados diferentes níveis de acessibilidade e aspectos relativos à história e memória local, além de um planejamento mais eficaz do processo de "reciclagem" das capacitações.

\section{CONSIDERAÇÕES FINAIS}

A particularidade socioespacial do Rio da Prata se apoia no processo de revalorização e ressignificação da natureza e da cultura de agricultores. Este processo aglutina signos sobre os quais uma nova noção de rural está sendo construída, fornecendo apelo necessário para o estabelecimento de fluxos de visitação. Neste contexto, a dinâmica socioeconômica está cada vez mais atrelada às atividades turísticas e de lazer, que facultam oportunidades de negócios e visibilizam modos de vida, ou seja, culturas associadas a grupos denominados tradicionais.

A configuração do processo em tela, aqui definido como turismização, revelou que o INEA não está integrado a outros órgãos públicos, que deveriam estar incluídos no processo, tais como os de turismo, lazer, agricultura e de políticas culturais e patrimônio. A ausência de parcerias e de planejamento conjunto com outros órgãos conduz a uma política de UP que privilegia aspectos cênicos e atividades junto à natureza, sendo o INEA o órgão responsável pela política de meio ambiente, que está induzindo o turismo no local. Soma-se isso à análise de ausência de diálogo entre os órgãos da esfera pública relacionados ao turismo e ao lazer, as acusações de empreendedores locais, moradores e agricultores quanto ao fato de não se sentirem contemplados, uma vez que não têm sua cultura e práticas inseridas no contexto de valorização local.

A despeito do descompasso entre a conciliação de interesses, consideramos ser possível caracterizar pela perspectiva do UP que o processo de turismização existente no local pode vir a se enquadrar no segmento do ecoturismo. Isto, pois, conforme Rosa (2017), o referido segmento busca estabelecer integração entre espaço natural, visitantes, turistas, moradores, educadores, pesquisadores, objetivando agregar valor social à UC de acordo com os princípios de conservação da biodiversidade e desenvolvimento socioeconômico.

Entretanto, para que o ecoturismo atinja sua total potencialidade, faz-se necessário investir na visibilização da cultura e da memória do grupo de agricultores. 
Bem como no fortalecimento de ações, de forma integrada, entre distintos órgãos públicos interligados por políticas voltadas para gestão e ordenamento do UP em UC. No caso analisado, a comunidade receptora, ao "reinventar a cultura rural", apresenta-se como nova protagonista do ecoturismo que ali desponta.

\section{REFERÊNCIAS}

Brasil. (2007). Decreto n. 6.040, de 07 de fevereiro de 2007. Institui a Política Nacional de Desenvolvimento Sustentável dos Povos e Comunidades Tradicionais. Diário Oficial, Brasília.

Embratur. (2019). Brasil terá programa de revitalização do ecoturismo. Referenciado de: https://bit.ly/387ZGI0.

Fernandez, A. C. (2016). O sertão virou parque: natureza, cultura e processos de patrimonialização. Estudos Históricos (Rio de Janeiro). 29(57), 129-148.

Fontoura, L. M. (2014). Uso Público e conservação da biodiversidade em parques nacionais do Brasil e Estados Unidos. Tese de Doutorado. Programa de Pós-Graduação em Ciências Ambientais e Florestais, Universidade Federal Rural do Rio de Janeiro, Rio de Janeiro.

Horochovski, M. T. (2004). Representações Sociais: Delineamentos de uma Categoria Analítica. Revista Eletrônica dos Pós-Graduandos em Sociologia Política da UFSC. 2(1), 92-106.

Instituto Estadual do Ambiente - INEA. (2013). Resumo Executivo do Plano de Manejo do Parque Estadual da Pedra Branca. Referenciado de: http://www.femerj.org/wpcontent/uploads/Plano-de-manejo-do-Parque-Estadual-da-Pedra-Branca-PEPBResumo-executivo.pdf. Acesso em: 18 jun. 2018

Leal, P. F. (2010). Construção do agricultor "orgânico". Raízes: Revista de Ciências Sociais e Econômicas. 30(2), 68-83.

Mendonça, T. C. (2010). Que paraíso éesse? A turismização da Ilha Grande. Tese de Doutorado. Instituto de Filosofia e Ciências Humanas, Universidade do Estado do Rio de Janeiro. Rio de Janeiro, Brasil.

Ministério do Meio Ambiente - MMA. (2015). Conflitos: estratégias de enfrentamento e mediação. Série educação ambiental e comunicação em Unidades de Conservação. Brasília.

Ministério do Turismo - MTur. (2010). Ecoturismo: Orientações Básicas. Brasília. Referenciado de: http://www.turismo.gov.br/sites/default/turismo/o_ministerio/ publicacoes/downloads_publicacoes/Ecoturismo_Versxo_Final_IMPRESSxO_pdf. Acesso em: 04 set. 2020.

Ministério do Turismo - MTur. (2019). MTur destaca importância do ecoturismo para economia brasileira. Referenciado de: https://bit.ly/2Z9pHCS. Acesso em: 04 set. 2020.

Ministério do Turismo - MTur. (2020). Número de visitantes em unidades de conservação aumenta 20\%. Referenciado de: https://bit.ly/2NCeV2s. Acesso em: 04 set. 2020.

Miranda, G. S. (2009). A expansão de condomínios fechados em Campo Grande: uma análise da segregação socioespacial na cidade do Rio de Janeiro a partir do "bairro" Rio da Prata. GeoPuc. v.2, 1-14. Acesso em: 04 set. 2020.

Moscovici, S. (1978). A representação social da psicanálise. Rio de Janeiro: Zahar Editores.

Oliveira, F. L. (2015). Triangulação metodológica e abordagem multimétodo na pesquisa sociológica: vantagens e desafios. Ciências Sociais Unisinos. 51(2), 133- 143.

Pena, I. A., \& Moss, M. C. (2017). Implementação do primeiro Curso de Capacitação de Condutores do Parque Estadual da Pedra Branca, RJ. Anais do VIII Seminário Brasileiro sobre Áreas Protegidas e Inclusão Social e III Encontro Latino-Americano sobre Áreas Protegidas e Inclusão Social: Repensando os paradigmas institucionais da conservação (pp. 1542-1554). Niterói: PPGSDUFF. 
Penna-Firme, R., \& Brondízio, E. S. (2017). Quilombolas como "Coletividades Verdes": contestando e incorporando o ambientalismo na Mata Atlântica, Brasil. Ambiente \& Sociedade. 20(2), 139-158.

Pereiro, X., \& Fernandes, F. (2018). Antropologia e Turismo: Teorias, métodos e praxis. Tenerife: Pasos, RTPC.

Pérez-Calderón, E., Prieto-Ballester, J. M., Miguel-Barrado, V., \& Milanés-Montero, P. (2020). Perception of Sustainability of Spanish National Parks: Public Use, Tourism and Rural Development. Sustainability. 12(4), 1333. MDPI AG.

Prado, B. A. (2012). A construção de modos de vida sustentáveis em torno da agricultura na cidade do Rio de Janeiro: agricultores do maciço da Pedra Branca. Dissertação de Mestrado. Programa de Pós-Graduação em Ciências Sociais em Desenvolvimento, Agricultura e Sociedade, Universidade Federal Rural do Rio de Janeiro. Rio de Janeiro, Brasil.

Rosa, C. R. (2017). Uso público em parques estaduais do Rio de Janeiro: perspectivas e desafios para a prestação de serviços de apoio à visitação. Dissertação de Mestrado. Programa de Pós-Graduação em Práticas em Desenvolvimento Sustentável, Universidade Federal Rural do Rio de Janeiro. Rio de Janeiro, Brasil.

Santos, R. A., Emiliano, A. S., \& Pagamisse, M. (2012). Discussões sobre a prática do turismo em ambientes naturais. Arguições por uma gestão participativa capaz de contemplar princípios para o usufruto sustentável de espaços rurais. Revista Científica Eletrônica de Turismo, n. 17.

Tribe, J. (1997). The (in) discipline of tourism. Annals of Tourism Research. 24(3), 638-657.

World Travel \& Tourism Council - WTTC. (2020a). Brazil - 2020 Annual Research: Key Highlights. Referenciado de: https://wttc.org/Research/Economic-Impact. Acesso em: 11 mai. 2020

World Travel \& Tourism Council - WTTC. (2020b). Economic Impact Reports: Top 20 Economies - Largest Contribution of Travel \& Tourism GDP. Referenciado de: https://wttc.org/Research/Economic-Impact. Acesso em: 11 mai. 2020

Zaoual, H. (2008). Do turismo de massa ao turismo situado: quais as transições? Caderno Virtual de Turismo. 8(2), 1-14.

Recebido em: 28/06/2020

Aprovado em: 09/08/2020

\section{CONTRIBUIÇÕES}

Maria Amália Silva Alves de Oliveira: Definição do problema de pesquisa e objetivos, desenvolvimento da proposição teórica, realização da revisão bibliográfica e fundamentação teórica, escolha dos procedimentos metodológicos, coleta e análise de dados, revisão crítica, redação do manuscrito e autora e coordenadora do projeto de pesquisa que originou o artigo em tela.

Ingrid Almeida de Barros Pena: Definição do problema de pesquisa e objetivos, desenvolvimento da proposição teórica, realização da revisão bibliográfica e fundamentação teórica, escolha dos procedimentos metodológicos, coleta e análise de dados, elaboração de tabelas, gráficos e figuras, revisão crítica, redação e postagem do manuscrito na plataforma da RTA.

Roberta Peixoto: Definição do problema de pesquisa e objetivos, análise de dados, elaboração de tabelas, gráficos e figuras, realização de cálculos e projeções, revisão crítica, redação e adequação do manuscrito às normas da RTA. 